\title{
Upper ocean stratification and sea ice growth rates during the summer-fall transition, as revealed by Elephant seal foraging in the Adélie Depression, East Antarctica
}

\author{
G. D. Williams ${ }^{1,2}$, M. Hindell ${ }^{3}$, M.-N. Houssais ${ }^{1}$, T. Tamura ${ }^{2}$, and I. C. Field ${ }^{4}$ \\ ${ }^{1}$ LOCEAN, Univerity of Pierre and Marie Curie, UMR 7159, Jussieu 75252 PARIS Cedex 05, France \\ ${ }^{2}$ ACE CRC Private Bag 80 Hobart TAS 7001, Australia \\ ${ }^{3}$ Institute for Marine and Antarctic Studies, University of Tasmania, Private Bag 129, Hobart TAS 7001, Australia \\ ${ }^{4}$ Graduate School of the Environment, Macquarie University, North Ryde NSW, 2109 Australia
}

Received: 15 October 2010 - Published in Ocean Sci. Discuss.: 16 November 2010

Revised: 14 February 2011 - Accepted: 24 February 2011 - Published: 11 March 2011

\begin{abstract}
Southern elephant seals (Mirounga leonina), fitted with Conductivity-Temperature-Depth sensors at Macquarie Island in January 2005 and 2010, collected unique oceanographic observations of the Adélie and George V Land continental shelf $\left(140-148^{\circ} \mathrm{E}\right)$ during the summer-fall transition (late February through April). This is a key region of dense shelf water formation from enhanced sea ice growth/brine rejection in the local coastal polynyas. In 2005, two seals occupied the continental shelf break near the grounded icebergs at the northern end of the Mertz Glacier Tongue for several weeks from the end of February. One of the seals migrated west to the Dibble Ice Tongue, apparently utilising the Antarctic Slope Front current near the continental shelf break. In 2010, immediately after that year's calving of the Mertz Glacier Tongue, two seals migrated to the same region but penetrated much further southwest across the Adélie Depression and sampled the Commonwealth Bay polynya from March through April. Here we present observations of the regional oceanography during the summer-fall transition, in particular (i) the zonal distribution of modified Circumpolar Deep Water exchange across the shelf break, (ii) the upper ocean stratification across the Adélie Depression, including alongside iceberg C-28 that calved from the Mertz Glacier and (iii) the convective overturning of the deep remnant seasonal mixed layer in Commonwealth Bay from sea ice growth. Heat and freshwater budgets to $200-300 \mathrm{~m}$ are used to estimate the ocean heat content $\left(400 \rightarrow 50 \mathrm{MJ} \mathrm{m}^{-2}\right)$,
\end{abstract}

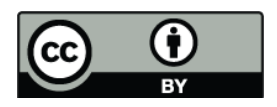

Correspondence to: G. D. Williams (guy.darvall.williams@gmail.com) flux $\left(50-200 \mathrm{~W} \mathrm{~m}^{-2}\right.$ loss) and sea ice growth rates (maximum of $7.5-12.5 \mathrm{~cm} \mathrm{day}^{-1}$ ). Mean seal-derived sea ice growth rates were within the range of satellite-derived estimates from 1992-2007 using ERA-Interim data. We speculate that the continuous foraging by the seals within Commonwealth Bay during the summer/fall transition was due to favorable feeding conditions resulting from the convective overturning of the deep seasonal mixed layer and chlorophyll maximum that is a reported feature of this location.

\section{Introduction}

One of the key challenges facing the global ocean climate modelling community, in particular in the Southern Ocean around Antarctica, is the scarcity of oceanographic observations that adequately describe the temporal and spatial variability. The introduction of the ARGO float program has made great steps to address this imbalance, supplying near real-time data on the ocean state. In association with this technology has come the deployment of similar instruments on marine mammals, birds and fish, which have proven very successful in collecting complementary and unique datasets to the ARGO float program (see Biuw et al. (2007); Boehme et al. (2008); Charrassin et al. (2008); Costa et al. (2008); Meredith et al. (2011) and references therein). However, the standard ARGO floats do not extend into the sea ice zone and whilst the newly developed and recently deployed IceARGO floats can, these are still limited to the north of the continental slope (ocean depths greater than $2000 \mathrm{~m}$ ). The most sparsely-observed and logistically difficult region is the

Published by Copernicus Publications on behalf of the European Geosciences Union. 


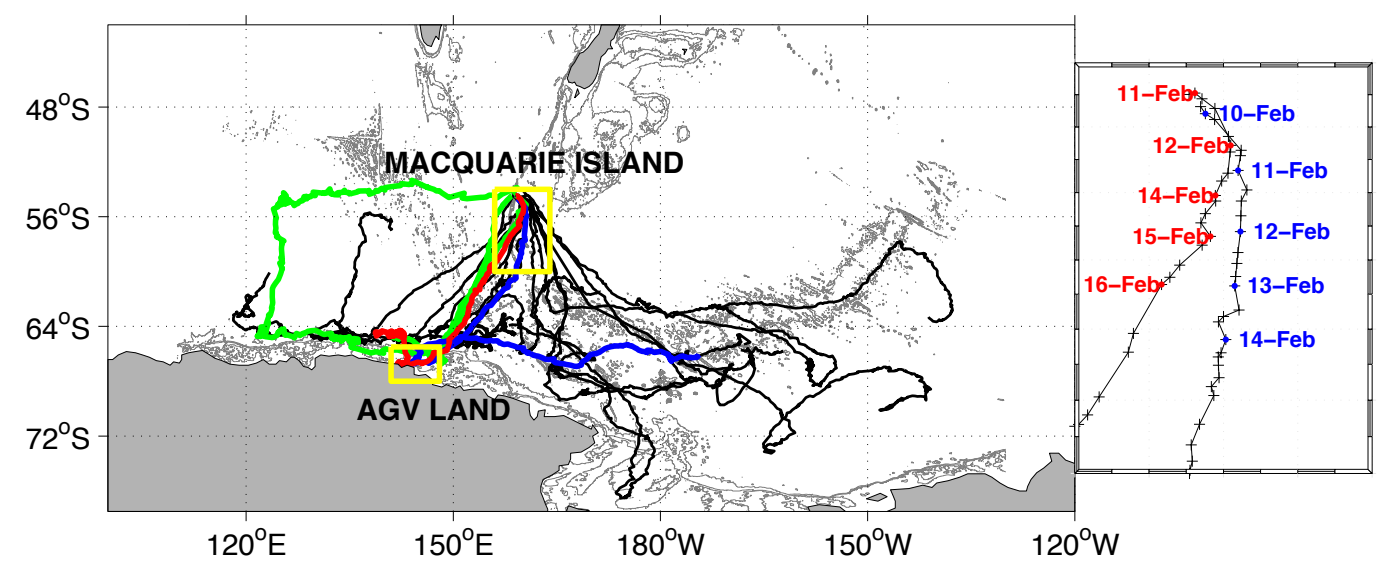

Fig. 1. Southern elephant seal tracks from IMOS in 2010 (black lines). Specific seals that sampled the Adélie and George V Land continental shelf: seals I1 and I2 (blue and red lines, respectively), and SEaOS seals (2005) S1 and S2 (green lines). Inset: Change in direction of seals I1 and I2 (blue and red, respectively) from SSE to SSW after leaving Macquarie Island (start) in February 2010, hypothesised to be in response to the calving of the Mertz Glacier Tongue (MGT).

Antarctic coastal region south of the continental shelf break. In this region, at specific seasons, biologically-mounted observation platforms are often the only source of in situ data.

Female elephant seals (Mirounga leonina) equipped with oceanographic sensors provide valuable observations on the environment, and the biological responses to its variability, around the Southern Ocean (Biuw et al., 2007; Bailleul et al., 2007). In the Australian/South Indian sector, southern elephant seals from Macquarie Island were tagged as part of the Southern Elephant as Oceanographic Samplers (SEaOS, http://biology.st-andrews.ac.uk/seaos/) and Integrated Marine Observing Systems through the Australian Animal Tracking and Monitoring System facility (IMOS/AATMS, hereafter IMOS - http://imos.org.au/aatams.html) programs. Nine and fifteen animals were tagged in 2005 (SEaOS) and 2010 (IMOS), respectively. Their annual migration south covered a wide region from $120^{\circ} \mathrm{E}-140^{\circ} \mathrm{W}$ (see Fig. 1). Conductivity-Temperature-Depth (CTD) data from the SEaOS and IMOS seals was collected on the continental shelf after the beginning of the sea ice growth season. Of particular interest here is the data collected from the Adélie and George V land (hereafter collectively referred to as AGV) region of East Antarctica (140-148 ${ }^{\circ}$ E, see Fig. 2), which is a key formation region of the dense shelf water precursor for Antarctic Bottom Water (AABW) produced in this sector (Gordon and Tchernia, 1972; Rintoul, 1998; Whitworth III, 2002).

AGV dense shelf water is formed during the austral winter (April-October) via brine rejection from enhanced sea ice formation in the coastal polynyas of this region (Williams et al., 2008a). When sufficiently dense and successfully exported north across the shelf break, this water mass mixes down the AGV continental slope to produce a local variety of Antarctic Bottom Water to the Australian-Antarctic
Basin (Williams et al., 2010a). Recent observational programs using standard ship-based CTD surveys and moored instrument arrays have described the seasonal cycle of water mass transformation in the Adélie Depression (Williams and Bindoff, 2003; Williams et al., 2008a). These observations have been essential for validating models seeking to predict the future sensitivity of dense shelf export from this region (Marsland et al., 2004, 2007; Kusahara et al., 2011a,b) and studies seeking to groundtruth estimates of sea ice production from satellite data (Tamura et al., 2008). Nonetheless logistic constraints have led to spatial and temporal gaps in the observations and consequently our understanding of the oceanography.

In this paper we detail new, unique oceanographic measurements for the Adélie Depression during the summer/fall transition from the SEaOS (February-March 2005) and IMOS (February-April 2010) deployments. In Sect. 2 we provide the background to the study region and its oceanography. Section 3 details the data and methods. Section 4 presents the seal-mounted CTD data and describes (i) the seasonal variability in the zonal distribution of modified Circumpolar Deep Water intrusions along the AGV shelf break, (ii) the vertical stratification across the Adélie Depression at the end of summer 2010 and (iii) the overturning of the remnant summer mixed layer at the start of the sea ice growth season in Commonwealth Bay, from late February through April 2010. We use the repeat profiling by the IMOS seals in Commonwealth Bay to estimate ocean heat content, heat flux and daily sea ice growth rates from heat and freshwater budgets in the upper 200-300 m. In Sect. 5 we compare the sea ice growth rates to satellite derived analyses and discuss new insights gained into the oceanographic processes of the region, speculating on how the Elephant seals may be utilising these to benefit their migration/foraging strategies. 


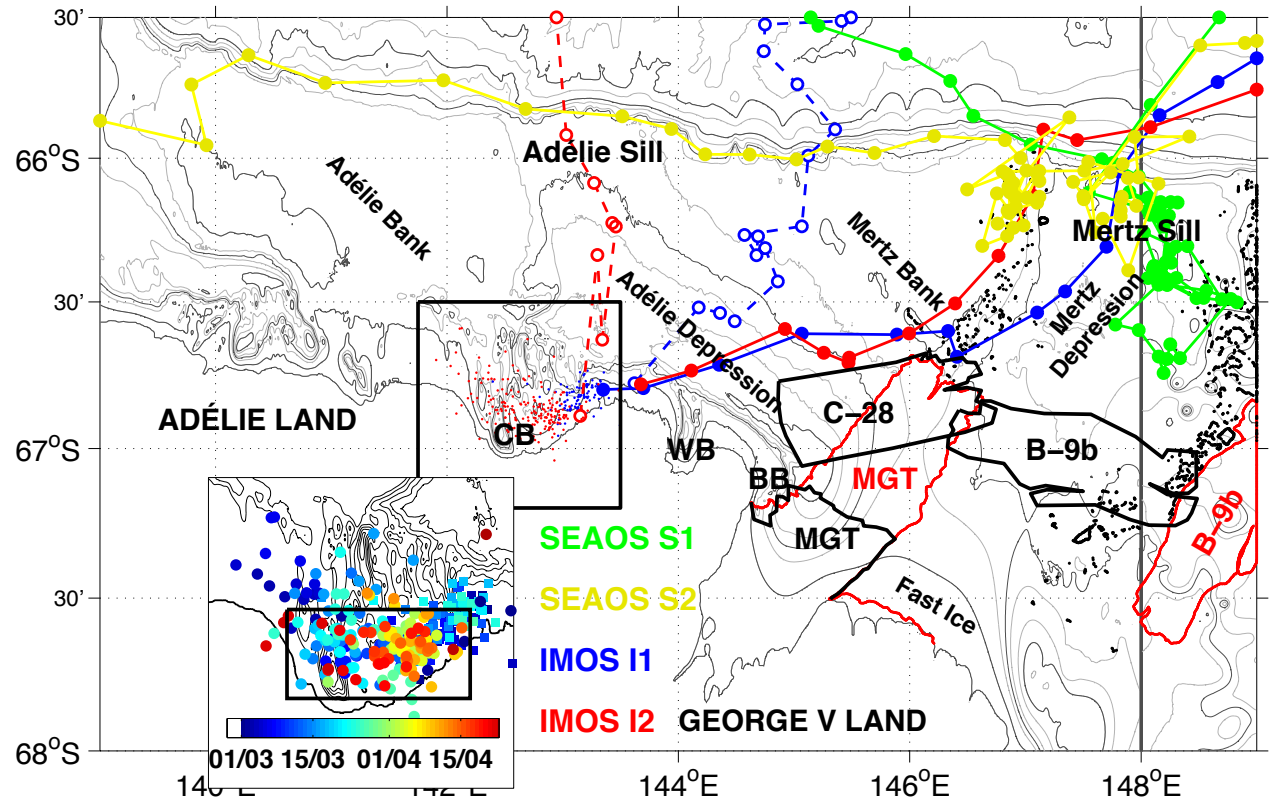

Fig. 2. The Adélie Depression and surrounds with $500 \mathrm{~m}$ resolution bathymetry from Beaman (2009) between $139-148^{\circ} \mathrm{E}$ and ETOPO1 (2009) from $148-149^{\circ}$ E. Major contour intervals shown for 4000, 3000, 2000, 1000, 500 and $200 \mathrm{~m}$. The minor contour interval is $100 \mathrm{~m}$ and $200 \mathrm{~m}$ north and south of the 1000-m isobath, respectively. Features include the Adélie Bank (AB), Adélie Depression (AD), the Adélie Sill (AS), Mertz Bank (MB), Mertz Depression (MD) and Mertz Sill (MS). Coastal embayments shown are Commonwealth Bay (CB), Watt Bay (WB) and Buchanan Bay (BB). Glacial features include the Mertz Glacier (MGT, pre-2010), iceberg B-9b and a fast ice region east of the MGT. Grounded icebergs indicated by black dots. The occupation of the Mertz Bank and Sill by SEaOS seals (S1 green-filled circles, S2 yellow-filled circles) and IMOS seals I1 and I2 (blue and red lines/circles, respectively) is shown. For the IMOS seals, filled circles/full lines indicate the pathway into the region (26-28 February) and the open circles/dashed lines indicate the exit pathway. The pre-calving position of the MGT and iceberg B9-b is shown in red. The post-calving position of iceberg C28 on the 26 February is indicated by the thick black line (digitized from a MODIS image). Inset shows timing of seal CTD profiles in the Commonwealth Bay area, the black box indicating the limit of data used for sea ice growth estimates.

\section{The Adélie and George $V$ land continental shelf}

\subsection{Bathymetry and glacial features}

Our study area is the Adélie Depression and surrounds (see Fig. 2 and 3), situated across the transition from Adélie Land $\left(136-142^{\circ} \mathrm{E}\right)$ to George V Land $\left(142-153^{\circ} \mathrm{E}\right)$. The Adélie Depression (AD), also referred to as the Mertz-Ninnis Trough, was formed during a previous extension of the continental ice sheet. The major cryospheric features are the floating extension of the Mertz Glacier Tongue (MGT), which prior to its calving in February 2010 extended nearly $100 \mathrm{~km}$ across the $\mathrm{AD}$ and onto a region of the continental shelf termed the Mertz Bank, and the enhanced sea ice produced in the coastal polynyas that form each winter. Historically the sea ice formation regions over the Adélie Depression have been collectively referred to as the Mertz Glacier Polynya. More recently there has been a sub-regionalisation distinguishing between the polynya in the western lee of the MGT and grounded icebergs to the north and the polynyas in the coastal bays to the west, namely Buchanan Bay, Watt Bay and Commonwealth Bay (from east to west). Massom et al.
(2001) suggested that along the coast the polynyas were more influenced by the katabatic wind system draining from the continent and that the polynya in the lee of the MGT was more influenced by synoptic systems, i.e., the interaction between the cold high-pressure system over the Antarctic continent and the band of westerly, warm low-pressure systems to the north.

Commonwealth Bay, infamously known as the "Home of the Blizzard" (Mawson, 1930), is the windiest sea-level location on earth, with mean annual wind speeds of $\sim 20 \mathrm{~ms}^{-1}$ (Parish and Wendler, 1991; Adolphs and Wendler, 1995). Bathymetrically, Commonwealth Bay is partially isolated from the greater Adélie Depression. Divided zonally, the main region of open water associated with the polynya is over relatively shallow coastal bathymetry in the eastern sector. The western sector has a more complex bathymetry, with 3-4 "holes" or sinkholes in the continental shelf that were discovered during a high-resolution SEABEAM survey in the austral summer of 2000-2001. The largest hole, hereafter referred to as the Commonwealth Bay Hole, is $875 \mathrm{~m}$ deep and isolated from the larger Adélie Depression below $375 \mathrm{~m}$. It effectively traps the dense shelf water formed in 


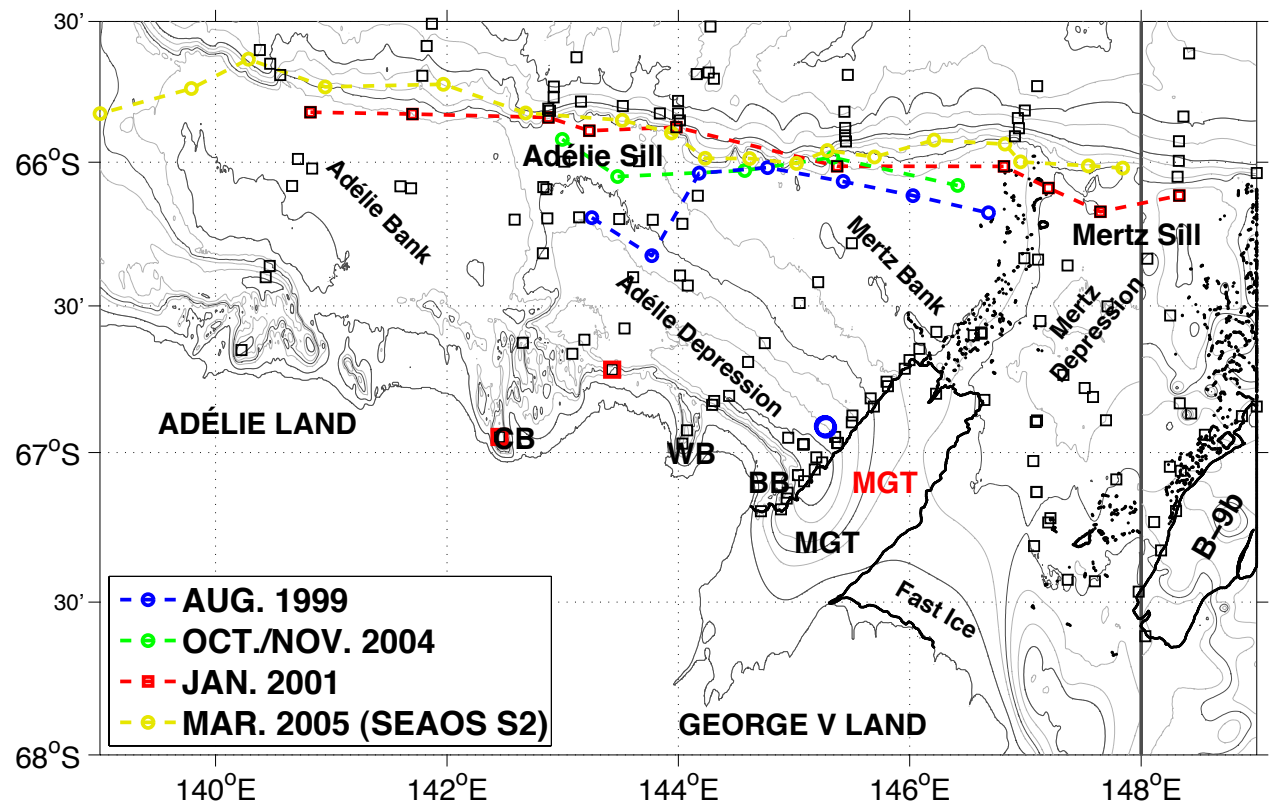

Fig. 3. The location of high quality ship-borne summertime CTD measurements from NBP00-08 (squares). Specific CTD locations also shown for Fig. 4 from summer near Commonwealth Bay (NBP00-08, stations 17 and 61, red squares) and from winter near the MGT over the AD (AU9901, stations 27, 51 and 84, blue circles). Seasonal shelf break transects for Fig. 6 indicated by dashed lines for winter (AU9901, blue), spring (NBP0410, green), summer (NBP00-08, red) and summer/fall (SEaOS, S2, black).

this region in winter, as detected during NBP00-08 (station 17) which found salinities as high as 34.77 , greater than anything observed in the greater Adélie Depression during the wintertime occupation of 1999 (Williams and Bindoff, 2003) or mooring deployments from April 1998 to February 2000 (Williams, 2004; Williams et al., 2008a).

\subsection{Water masses}

The seasonal cycle of water mass transformations in the Adélie Depression is primarily surface-driven by the annual growth and decay of sea ice (Williams et al., 2008a). In addition there is seasonally variable lateral input at mid-depths from warm modified Circumpolar Deep Water (mCDW) incursions across the shelf break and cold Ice Shelf Water (ISW) from ocean/ice shelf interactions beneath the Mertz Glacier. Figure $4 a-b$ shows the spatial distribution of mCDW and ISW, following the definitions of Orsi and Wierderwahl (2009), using bottle-calibrated CTD data from the NBP0008 summertime survey aboard the RVIB Nathaniel B Palmer in January 2001 (Jacobs et al., 2004).

The intensity of the mCDW intrusions, depicted as the potential temperature $\left({ }^{\circ} \mathrm{C}\right)$ at the dissolved oxygen minimum within the mCDW layer $\left(28.00<\gamma^{n}<28.27 \mathrm{~kg} \mathrm{~m}^{-3}\right)$, describes the transport of mCDW over the shelf break and into the Adélie Depression through the eastern part of the Adélie Sill, and to a lesser extent into the Mertz Depression region $\left(147-148.5^{\circ} \mathrm{E}\right)$. The $\mathrm{mCDW}$ signal weakens to the south and is not detected in stations against the coast, in particular the interior of Commonwealth Bay. While there is an additional intrusion to the east at $140^{\circ} \mathrm{E}$, there is no evidence of this mCDW communicating eastwards across the Adélie Bank into the Adélie Depression. The spatial distribution of ISW, as indicated by potential temperatures colder than $-1.95^{\circ} \mathrm{C}$, extends northwestwards from Buchanan Bay, quickly losing its cold signature through mixing with the summertime water masses. As in the case of $\mathrm{mCDW}$, we assume there is no direct influence of ISW into Commonwealth Bay, though both water masses are likely to be indirectly mixed into the local shelf water properties.

The seasonal change in vertical stratification from summer to winter is demonstrated in Fig. 4c, using two summertime CTD profiles from Commonwealth Bay (station 17 and 62 from NBP00-08), and CTD profiles from the Adélie Depression against the MGT collected during the Mertz Polynya Experiment, hereafter labelled as A9901 (Rosenberg et al., 2001), in July-August 1999 that best represent the bulk winter properties (stations 27, 51, 84). The locations of these stations are shown in Fig. 3. The wintertime oceanography over the Adélie Depression is dominated by the formation of dense shelf water at freezing temperatures and increasing salinity throughout the water column in response to polynya activity, with only minor contributions from mCDW and ISW (Williams and Bindoff, 2003; Williams et al., 2008a). The water column is near-homogeneous in both salinity and temperature (see Fig. 4c-e). In summer the upper water 

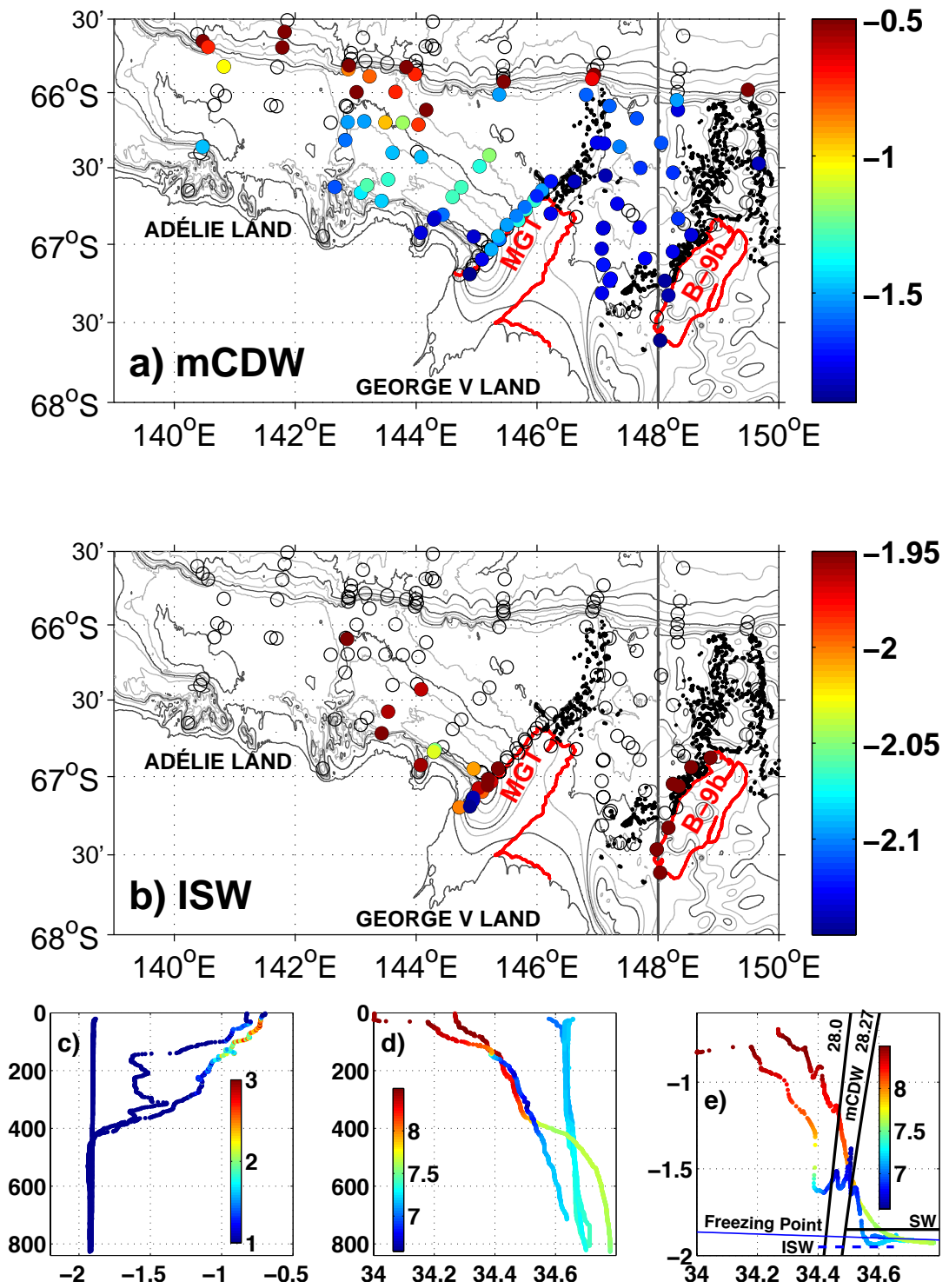

Fig. 4. Summary of regional water masses and seasonal stratification from historical ship-based CTD data. Planform distribution of (a) mCDW and (b) ISW from the NBP00-08 summertime CTD surveys. MCDW intensity indicated by potential temperature $\left(^{\circ}\right)$ at the dissolved oxygen minimum within the mCDW layer $\left(28.00<\gamma^{n}<28.27\right)$. ISW intensity shown as potential temperature $\left(<-1.94{ }^{\circ} \mathrm{C}\right)$. Panels $\mathbf{c}-\mathbf{e}$ shows characteristic vertical profiles and $\theta-S$ diagrams for summer (stations 17 and 61 from NBP00-08 in Commonwealth Bay) and winter (stations 27, 51 and 84 from A9901 over the Adélie Depression north of Watt Bay). Color scale is raw CTD-fluoresence for the vertical profile of potential temperature and dissolved oxygen $\left(\mathrm{mLL}^{-1}\right)$ for salinity and the $\theta-S$ diagram. In Fig. 4e, the black contours of $\gamma^{n}=$ 28.00 and $28.27 \mathrm{~kg} \mathrm{~m}^{-3}$ define the mCDW layer and the black horizontal line is the maximum temperature $(\theta<=-1.85)$ for Shelf Water. The thick dashed blue line is the maximum temperature $\left(\theta<=-1.95^{\circ} \mathrm{C}\right)$ for ISW and the thin blue line is the surface freezing point.

column re-stratifies, as a warm, fresh and oxygen-rich Seasonal Mixed Layer (SML) forms at the surface from the wind driven convection of sea ice melt. The SML in Commonwealth Bay is the deepest for the region at $350 \mathrm{~m}$ as reported by Vaillancourt et al. (2003). Station 17 from NBP00-08 in Commonwealth Bay also demonstrates the previously mentioned salinity maximum of 34.77 at depth within the Commonwealth Bay Hole. The main temporal gap in our obser- vational datasets of an Antarctic polynya region such as this, is the summer/fall transition that preconditions the full-depth convective winter mixed layer capable of forming dense shelf water, and it is this specific period that we focus on in this paper. 


\section{Datasets and methods}

\subsection{Seal-derived CTD measurements}

\subsubsection{The SEaOS survey}

The migration of the SEaOS and IMOS seals, equipped with autonomous CTD-Satellite Relay Data Loggers (CTDSDRL) at Macquarie Island, around the AGV continental shelf is detailed in Fig. 2. In late February 2005, two of nine $\mathrm{SEaOS}$ seals tracked from Macquarie Island entered the region near the Mertz Sill. In this paper we will refer to these SEaOS seals as S1 and S2, with corresponding GTS identification numbers 38566 and 43855, respectively. Seal S1 (green filled circles, Fig. 2) surveyed the eastern sector of the Mertz Depression region and then exited the region near $147^{\circ} \mathrm{E}$ at the end of March. Seal S2 (yellow circles, Fig. 2) also entered the region through the Mertz Sill, but did not penetrate as far south into the Mertz Depression, remaining in the western sector of the sill region before moving to the western lee of the grounded icebergs near the Mertz Bank. Whereas seal S1 rapidly headed northwest away from the region, seal S2 migrated west to the Dibble Ice Tongue along the upper continental slope immediately north of the shelf break from 12-18 March. This trajectory is similar to those of icebergs transported by the Antarctic Slope Current (Aoki, 2003), which often includes a narrow, fast westward jet close to the 1000-m isobath (Williams et al., 2008a, 2010b).

\subsubsection{The IMOS survey}

In 2010, two of the fifteen IMOS seals equipped with CTDSDRL instruments on Macquarie Island also chose to migrate south to the AGV region. In this paper we will refer to these SEaOS seals as I1 and I2, with corresponding GTS identification numbers 55044 and 55052, respectively. Both seals were originally heading SSE, but then between 12-14 February changed direction to the SSW (see Fig. 1b). Interestingly this coincides with the reported timing of the calving of the MGT (B. Legrésy, personal communication, 2010). As in the case of the SEaOS seal, both IMOS seals approached the region through the Mertz Sill area, I1 (blue filled circles, Fig. 2) entering through the centre and I2 (red filled circles, Fig. 2) following two days later on the shallow topography to the west. Both seals then tracked closely, albeit 2-3 days apart, to the southern end of the grounded iceberg zone at $146^{\circ} \mathrm{E}$. The seals then moved along the northern flank of iceberg C28 that had recently calved from the MGT, en route to Commonwealth Bay at the end of February/ beginning of March. In Commonwealth Bay, I1 stayed in the eastern sector and departed (blue open circles, Fig. 2) on 26 March, collecting 55 profiles. I 2 stayed nearly one month later, until 26 April (thereafter red open circles, Fig. 2), and occupied a wider area of Commonwealth Bay across both east and west sectors.

\subsubsection{Instrumentation}

As detailed in Boehme et al. (2008), the autonomous CTDSDRLs used in the SEaOS and IMOS programs were constructed at the Sea Mammal Research Unit (SMRU) at the University of St Andrews, using a CTD sensor package built and calibrated by Valeport Ltd, Devon, UK. These units were harmlessly fixed to the seals fur after their annual moult in January/February. The data was relayed via the ARGOS system and distributed through the SMRU website. Previous studies have used comparisons of CTD-SDRL data with nearby ship-based CTD data to assess the accuracy of the salinity and temperature data. Unfortunately there is no useful ship-based data relevant to the timing and location of the data being used in this paper. Therefore following Boehme et al. (2008) we assume the uncertainty in both salinity and temperature to be 0.02 . Basic post-processing was completed to remove all data points associated with density inversions in the profiles, with a $10 \%$ reduction in data. The assumption is made that the sensors are not accurate enough to detect instabilities in density due to the overturning from brine rejection at the surface. One area of known problems is the ARGOS satellite telemetry error associated with location of the CTD profiles (Vincent et al., 2002; Patterson et al., 2010). In this paper we use the original location data, which is clearly not perfect given the handful of points that are on land (see Fig. 2a: Inset), but sufficient for this particular study.

\subsection{Estimation of heat content, flux and sea ice growth rates}

Following Costa et al. (2008) we estimate the upper Ocean Heat Content $\left(\mathrm{OHC}, \mathrm{J} \mathrm{m}^{-2}\right)$ by calculating the heat content relative to the in situ freezing point $\left(T-T_{f}\right)$ and integrating it over a range of depths (e.g., $z_{1}=-6 \mathrm{~m}, z_{2}=-50,-100$, $-200,-300 \mathrm{~m})$ as follows:

$\mathrm{OHC}=\int_{z_{2}}^{z_{1}} \rho_{z} c_{p_{z}}\left(T_{z}-T_{f_{z}}\right) d z$

where $\rho_{z}$ and $c_{p_{z}}$ are the in situ density $\left(\mathrm{kg} \mathrm{m}^{-3}\right)$ and specific heat of seawater $\left(\mathrm{J}^{\circ} \mathrm{C}^{-1} \mathrm{~kg}^{-1}\right)$. We then time difference this to get the OHC Flux (OHCF, $\mathrm{W} \mathrm{m}^{-2}$ ).

$\mathrm{OHCF}=d(\mathrm{OHF}) / d t$

We estimate sea ice production using the salinity budget method detailed in Charrassin et al. (2008).

$\rho_{o} V_{o} S_{o}=\rho_{o} V_{f} S_{f}+\rho_{i} V_{i} S_{i}$

where $\rho_{o}$ is the sea water density $=1027 \mathrm{~kg} \mathrm{~m}^{-3} ; V_{o}$ is the initial volume of water, with initial salinity $S_{o} ; V_{i}$ is the volume of ice formed with density $\rho_{i}=920 \mathrm{~kg} \mathrm{~m}^{-3}$ and salinity 10 ; and $V_{f}=V_{o}-V_{i}$ is the final volume of the seawater with salinity $S_{f}$. 
01/03-07/03

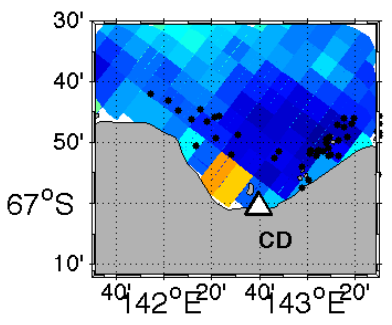

22/03-28/03

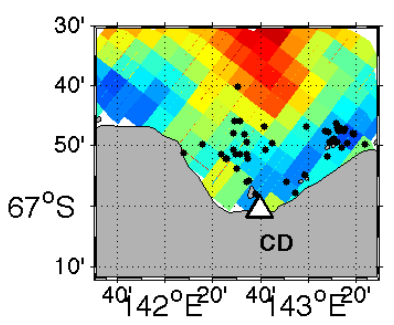

12/04-18/04

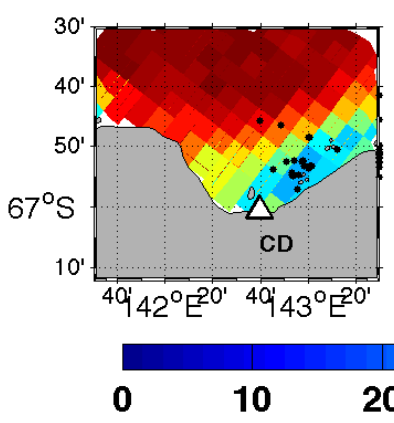

08/03-14/03

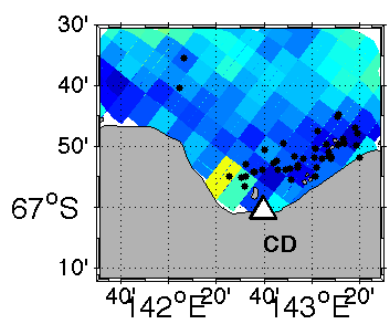

29/03-04/04

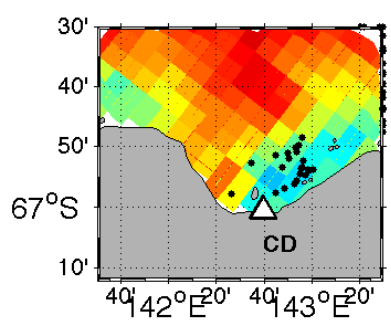

19/04-25/04

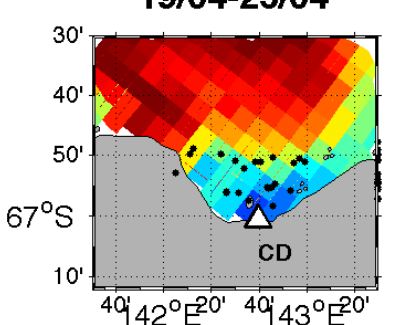

15/03-21/03

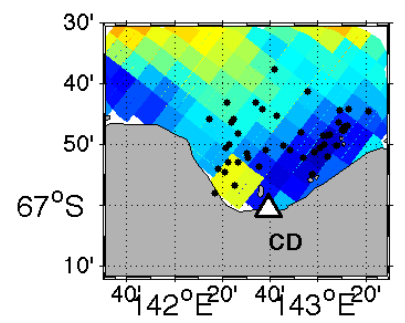

05/04-11/04

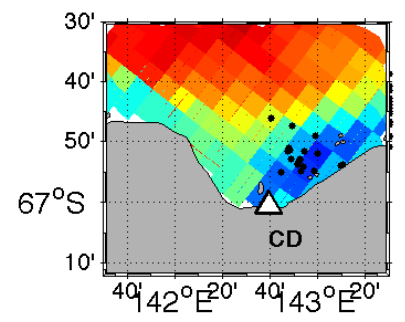

26/04-02/05

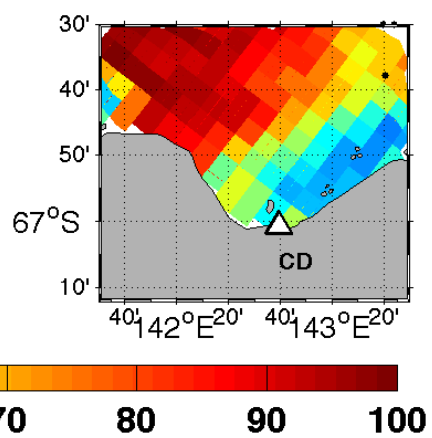

Fig. 5. Weekly locations of IMOS seals I1 and I2 (black dots) within Commonwealth Bay with mean sea ice concentration from AMSR-E (AMSR-E, 2008) from March through April 2010. Location of Cape Denison (CD) Automatic Weather Station as indicated by the triangle.

\subsection{Environmental data}

\subsubsection{Satellite derived sea ice concentration}

In this paper we use AMSR-E sea ice concentration data (AMSR-E, 2008) to examine the co-location of the seals' movements with the open water areas of the Commonwealth Bay Polynya. Figure 5 shows the weekly mean sea ice concentration with corresponding seal locations from March through April. For the first few weeks there is relatively low sea ice concentration across the region. In week 1 the seals aggregate on both the western and eastern sectors. Towards the end of March the sea ice concentration is developing in the offshore region and the morphology of the Commonwealth Bay polynya takes definition in the central/eastern sector. This pattern is consistent in April and the seals are co-located with the region of greatest open water/lowest sea ice concentration.

\subsubsection{AWS data from Cape Denison}

For many years there has been an automatic weather station on the coast at Cape Denison (AWS, 2010) but the extreme wind regime has made it very difficult to collect robust and ongoing wind measurements. ${ }^{1}$. For our study period there were no reliable wind measurements. In the Discussion section of this paper we present the available data for air temperature $\left({ }^{\circ} \mathrm{C}\right)$ and air pressure $(\mathrm{hPa})$. Ten-minute data was available across March through April, with a short break between 30 March and the 5 April.

1“The Adélie coast is bad news," says Matthew Lazzara (principal investigator for the AWS program and Antarctic Meteorological Center at the University of Wisconsin-Madison). "Its a place to throw away hardware.", from The Antarctic Sun, http: //antarcticsun.usap.gov/science/contenthandler.cfm?id=2031. 
Potential Temperature ( C) - AUGUST 1999

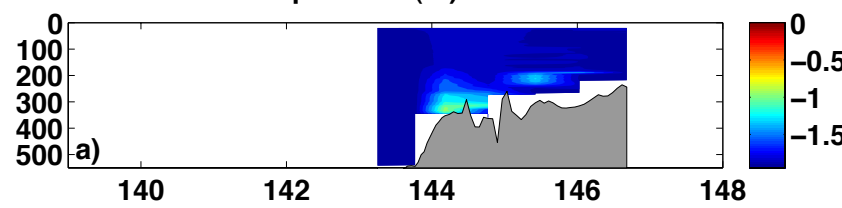

Potential Temperature (C) - ОСTOBER 2004

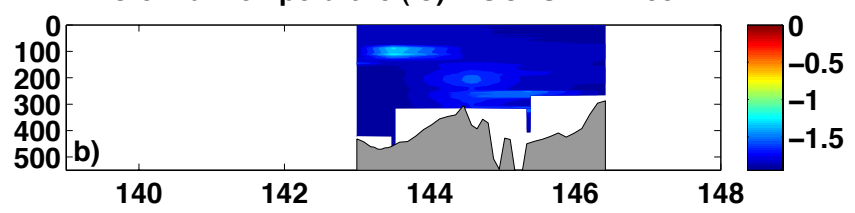

Potential Temperature (C) - JANUARY 2001

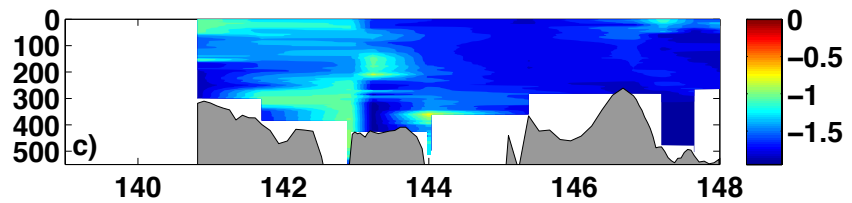

Dissolved Oxygen $\left(\mathrm{mL} \mathrm{L}^{-1}\right)$ - JANUARY 2001

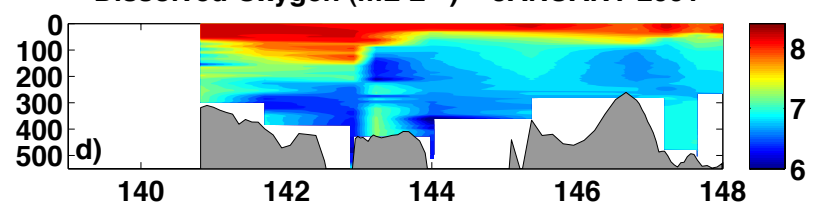

Potential Temperature (C) - MARCH 2005

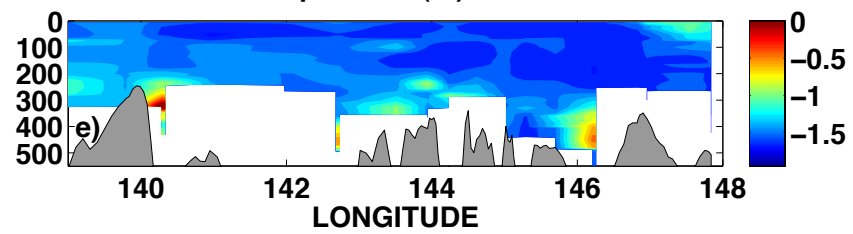

Fig. 6. Vertical sections of potential temperature $\left({ }^{\circ} \mathrm{C}\right)$ across the AGV shelf break. Panels a-e (from top to bottom): winter (August 1999, A9901); spring (October 2004, NBP04-10); summer (January 2001, NBP00-01); summer, dissolved oxygen $\left(\mathrm{mL} \mathrm{L}^{-1}\right)$; and summer/fall (March 2005, SEaOS).

\section{Results}

\subsection{Seasonal distribution of modified circumpolar deep water intrusions}

Previous ship-based CTD surveys have provided some seasonal coverage of the shelf break region (see Fig. 3). Figure 6 shows vertical sections of potential temperature for all four seasonal transects: A9901 (winter, Fig. 6a) with the RV Aurora Australis in August 1999, and NBP04-10 (spring, Fig. 6b) and NBP00-08 (summer, Fig. 6c) with the RVIB Nathaniel B Palmer in October 2004 and January 2001, respectively. The CTD transect provided by the SEaOS seal movement complements these data by detailing the water masses and stratification in early March 2005 (Fig. 6e). An additional section is provided for NBP00-08 (summer) showing the dissolved oxygen ( $\mathrm{mL} \mathrm{L}^{-1}$, Fig. 6d) to help delineate the warm/low oxygen mCDW signature at bottomto-mid depths from the warm/high oxygen properties of the ice-free summer mixed layer above. Though the transects are from different years and do not perfectly repeat in a region of abrupt changes in depth, they offer the most complete picture of the temporal and spatial variability in mCDW intrusions.

Starting in winter (Fig. 6a), the relatively small coverage between $143-146^{\circ} \mathrm{E}$ identified $\mathrm{mCDW}$ as warm as $-1^{\circ} \mathrm{C}$ below $200 \mathrm{~m}$ between $144-145^{\circ} \mathrm{E}$, east of the Adélie Sill. In spring (Fig. 6b, late October 2004), the water column is predominantly cold, dense shelf water. The shelf-break transect showed weaker mCDW properties relative to August. While this could be variability in the strength, timing and location of mCDW intrusions for this region, we can also expect that this could be related to the increase in shelf water from August-October through the last part of the sea ice growth season (Williams et al., 2008b), which presents a density barrier that blocks/dilutes the $\mathrm{mCDW}$ intrusions/properties. For summer (Fig. 6c-d), the transect from NBP00-08 extended from $141-148^{\circ} \mathrm{E}$ and showed the main core of warm, oxygen-poor mCDW over the Adélie Sill between $142-143^{\circ} \mathrm{E}$.

The SEaOS transect in early March covered a similar region and showed the most numerous profiles with evidence of warm mCDW, of all seasons (Fig. 6e). The same mCDW region east of the Adélie Sill was observed, however even stronger signals were detected upstream near the Mertz Sill $\left(146-147^{\circ} \mathrm{E}\right)$, and downstream west of the Adélie Bank (140-141 $\left.{ }^{\circ} \mathrm{E}\right)$ near the entrance to the D'Urville Trough. The mCDW near the D'Urville Trough, and to a lesser extent at the Mertz Sill, is near $0^{\circ} \mathrm{C}$ and indicative of the close proximity of the Antarctic Slope Front. This transect also shows the change in the vertical stratification of the Antarctic Surface Water (AASW) layer above the $\mathrm{mCDW}$, in particular from $141-144^{\circ} \mathrm{E}$ (Fig. 6d). By March this warmer summer mixed layer has been eroded and the preconditioning of the new winter mixed layer has begun(Fig. 6e).

\subsection{Upper water mass properties across the Adélie Depression in 2010 post-MGT calving}

The MGT calved around the 12-13 February 2010 after the mega-iceberg B9-b repositioned itself. The resulting $75 \mathrm{~km}$ iceberg C-28 had a short existence, breaking up further after the 10 March near the Adélie Sill before leaving the region completely. Both seals arrived in the Adélie Depression when $\mathrm{C}-28$ had pivoted clockwise on its northern point, prior to its movement across the Adélie Depression, and completed ENE-WSW CTD transects across the northern flank of C-28 en route to Commonwealth Bay. Vertical sections of salinity and potential temperature for these transects are shown in Fig. 7. In the Antarctic Surface Water (AASW) layer, from east $\left(145-147^{\circ} \mathrm{E}\right)$ to west $\left(143-145^{\circ} \mathrm{E}\right)$ there is a freshening of the layer and a deepening of the seasonal 


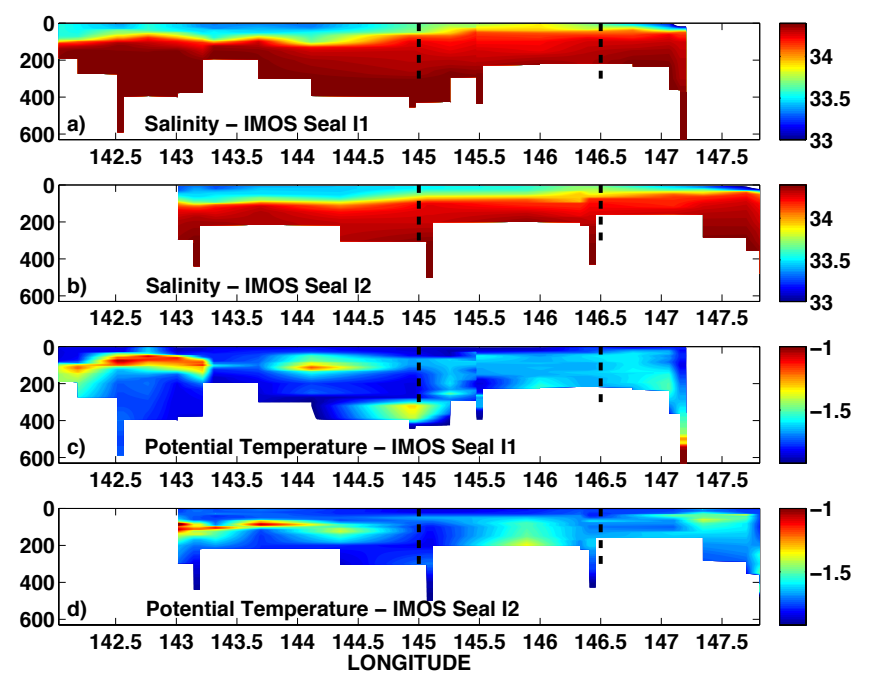

Fig. 7. Vertical sections of salinity (panels a-b) and potential temperature $\left(\mathrm{C}^{\circ}\right.$, panels $\left.\mathbf{c}-\mathbf{d}\right)$ across the Adélie Depression 25-28th February from IMOS seals I1 and I2, respectively. Vertical black dashed lines indicate the zonal location of iceberg C-28 between $\sim 145-147^{\circ} \mathrm{E}$

pycnocline that defines its base. This is likely to be the result of increased exposure to wind mixing and a greater amount of ice-free time closer to the coast in the west (Williams et al., $2008 \mathrm{~b}, 2010 \mathrm{~b})$. The surface water is cooled to near the freezing point; the remnant summer mixed layer is observed in the west, at depths between $50-150 \mathrm{~m}$ between $144-145^{\circ} \mathrm{E}$ and in Commonwealth Bay between $142-143^{\circ}$ E. Warm water anomalies below this depth are associated with $\mathrm{mCDW}$ intrusions which are more dominant in the north-east. There was no detection of ISW in potential temperature.

Both seals completed deep dives when near the C-28 iceberg, often diving to greater than $400 \mathrm{~m}$. This is also the estimated depth of the iceberg. It is possible that the seals explored beneath the iceberg during these dives. While the profiles collected by seals in this location had the potential to observe ocean/ice shelf interaction, there were cold excursions from the surface freezing point in the vertical profiles of potential temperature. Seal I2 came the closest, as indicated near $145^{\circ} \mathrm{E}$ in Fig. $7 \mathrm{~d}$. As introduced earlier, the volume of ISW is relatively small and the spatial impact on water mass properties are limited to the immediate region around Buchanan Bay. The seal CTD instruments would require greater precision to detect such subtle changes.

\subsection{Preconditioning of the winter mixed layer in Commonwealth Bay}

The nine week occupation of Commonwealth Bay by seals I1 and $\mathrm{I} 2$ resulted in a unique dataset of CTD profiling through the upper layer of a coastal Antarctic polynya. In total, seals I1 and I 2 collected 216 CTD profiles within the Common- wealth Bay region from the 1st March to the 25 April (seal I1: 55 profiles from 1st March to 27 March and seal I2: 161 profiles from 2 March to the 25 April). The mean depth and standard deviation of these profiles were $324 \pm 88 \mathrm{~m}$ and $367 \pm 92 \mathrm{~m}$ for seals $\mathrm{I} 1$ and $\mathrm{I} 2$, respectively. Vertical sections of salinity, potential temperature $\left({ }^{\circ} \mathrm{C}\right)$ and potential density anomaly $\left(\mathrm{kg} \mathrm{m}^{-3}\right)$, presented in Fig. 8, clearly show the erosion of the warm, fresh subsurface remnant of the summer mixed layer. The surface layer is already cold, indicating that the first phase of atmospheric cooling has already eroded the upper part of the summer mixed layer. Surface salinity increases from the beginning of the record, indicating that the secondary phase of sea ice formation/brine rejection has also already begun. There is a clear shoaling of the $S=34$ isohaline through March until the week leading into April when there is a deepening and freshening/cooling.

Figure 9 also presents the same time evolution of the upper water column using vertical profiles of salinity (Fig. 9a) and potential temperature $\left({ }^{\circ} \mathrm{C}\right.$, Fig. $\left.9 \mathrm{~b}\right)$ and combined $\theta-S$ space (Fig. 9c). The most dramatic changes occur in the surface layer, in conjunction with a broad shift in the deep water mass properties to colder, more saline values. One historical cast from NBP00-08 (dark gray line) is included. We note that seal $\mathrm{I} 2$ occupied the Commonwealth Bay hole in its deepest dive to $>750 \mathrm{~m}$, and recorded a maximum salinity of 34.86 (uncalibrated), higher than the maximum of 34.77 from the NBP00-08 measurement in January 2001 (station 17, Fig. 4d). As described earlier, the salinity maximum in this location is a proxy for the previous season's polynya activity/sea ice production and so this qualitatively implies that there was more dense shelf water formed in this region in 2009 than 2000. For potential temperature, it is clear that the surface layer in Commonwealth Bay was already cooled relative to the historical summertime profiles before the seals arrived. In $\theta-S$ space $\left({ }^{\circ} \mathrm{C}\right.$, Fig. $\left.9 \mathrm{c}\right)$, the data points collapse with time towards the freezing point line as the water column becomes relatively homogeneous Shelf Water.

\subsubsection{Upper ocean heat content and flux}

The time-series in Figs 8-9 showed the erosion of the remnant summer stratification in the preconditioning of the new winter mixed layer. We now consider a 1-D model for the temperature budget and in Fig. 10 present the Ocean Heat Content (OHC, Eq. 1), i.e., how much heat is present in the upper water column during the summer/fall transition, and the Ocean Heat Content Flux (OHCF, Eq. 2), i.e. the time rate at which the heat content changes. This is not to be confused with the ocean heat flux into the sea ice. In the absence of any lateral advection of heat into the region, e.g., via $\mathrm{mCDW}$, both the $\mathrm{OHC}$ and $\mathrm{OHCF}$ can be expected to decrease and asymptote towards zero as the water column is returned to the freezing point. Figure 10a shows time-series of the 4-day running mean of hourly potential temperature data near the surface $(6 \mathrm{~m})$ and averaged over the 50 and $200 \mathrm{~m}$ 

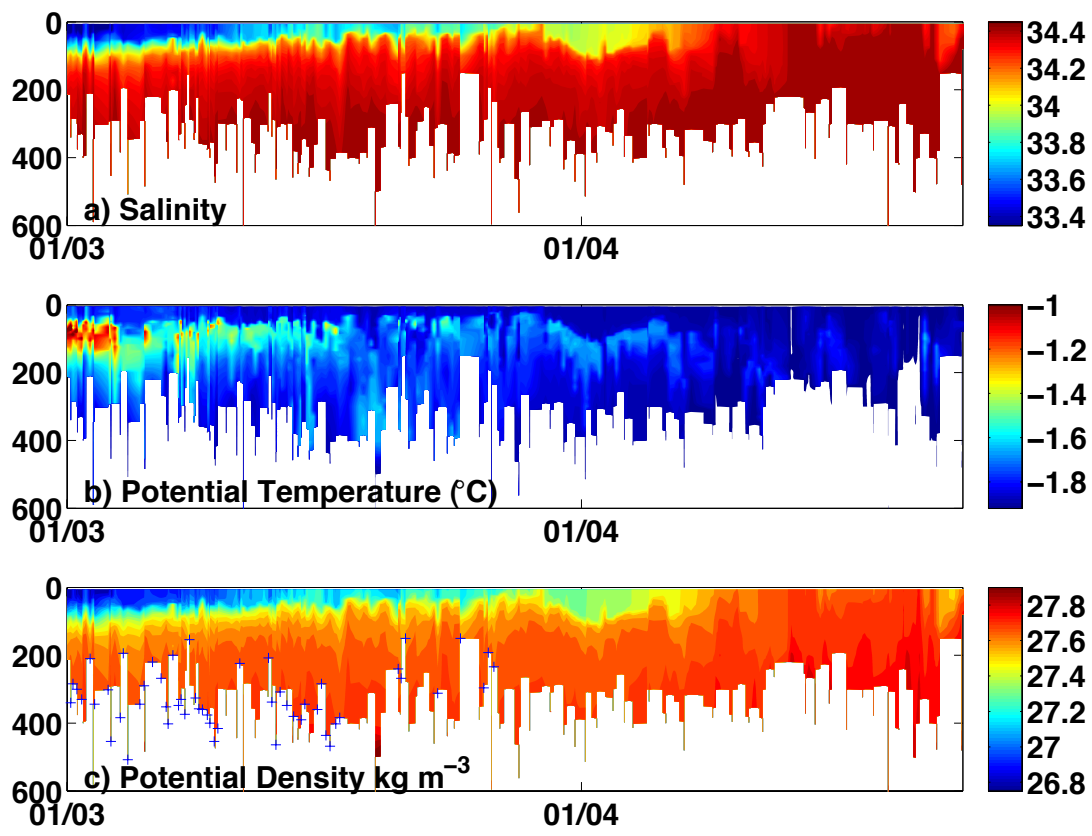

Fig. 8. Vertical sections of (a) salinity, (b) potential temperature $\left(\mathrm{C}^{\circ}\right)$ and (c) potential density $\left(\mathrm{kg} \mathrm{m}^{-3}\right)$ for seal CTD data in Commonwealth Bay. Profiles collected by seal I1 indicated by blue “+” symbol.
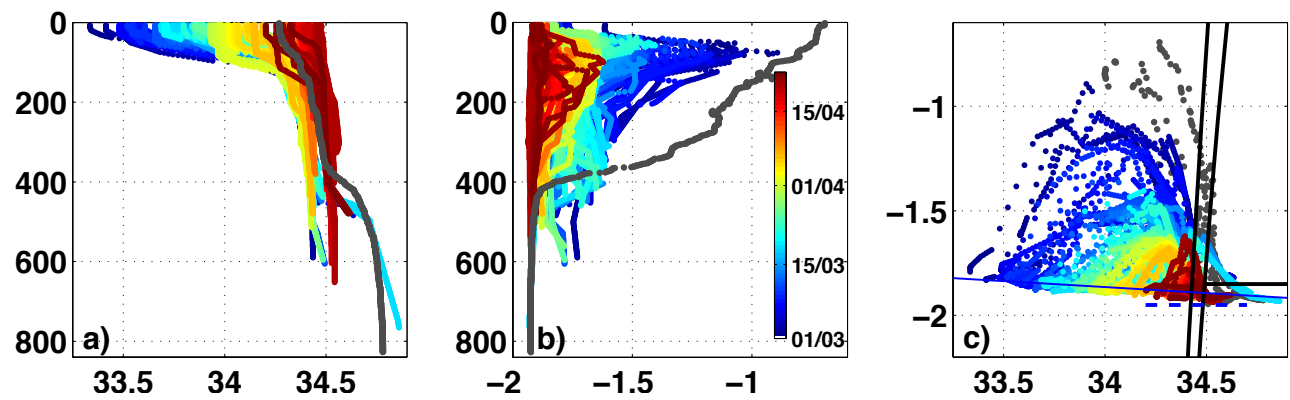

Fig. 9. IMOS seal CTD data with nearest bottled calibrated ship based CTD data from NBP00-08 (station 17), in dark gray, respectively). Panels $\mathbf{a}-\mathbf{b}$ are vertical profiles of salinity and potential temperature $\left(\mathrm{C}^{\circ}\right)$. Panel $\left.\mathbf{c}\right)$ is the $\theta-S$ diagram. Additional water mass boundaries, contours and freezing point line as in Fig. 4e. The color scale on all panels is the date.

depth ranges. The surface value reaches the freezing point on 13 March, though it is likely that sea ice growth has already started prior to this point, since the mean salinity is increasing at all levels from 1 March (Fig. 10d). That this occurs when the temperature is not at the freezing point indicates that there is small-scale freezing occuring in the very surface/skin layer (0-6 m).

The hourly $\mathrm{OHC}$ averaged over the $200 \mathrm{~m}$ depth range across the Commonwealth Bay region is $\sim 400 \mathrm{MJ} \mathrm{m}^{-2}$ at the beginning of March and decreases to $\sim 50 \mathrm{MJ} \mathrm{m}^{-2}$ at the end of April (green line in Fig. 10b). An 8-day running mean was applied to smooth the high frequency perturbations associated with the movement of the seal and internal dynamics within the survey area (blue line in Fig. 10b). Based on the OHF trend, assuming no further net advection of heat into the region from $\mathrm{mCDW}$ or otherwise, the $\mathrm{OHC}$ in the upper $200 \mathrm{~m}$ is expected to have reached zero in the first week of May 2010. The OHCF based on this 8-day running mean (blue line in Fig. 10c) fluctuates on roughly synoptic timescales, reaching $\sim-200 \mathrm{~W} \mathrm{~m}^{-2}$ in a peak period between 9-16 March. After 20 March there is a transition to weaker OHFC, peaking at $-100 \mathrm{~W} \mathrm{~m}^{-2}$ thereafter. Overall, whilst the OHCF is very sensitive to small changes in the mean layer properties, we do find a pattern of net heat loss from the region consistent with our earlier finding from summertime ship-borne CTD data (see Fig. 4a), that Commonwealth Bay is removed from the major pathways of mCDW influence in the Adélie Depression. 


\subsubsection{Sea-ice growth rates}

We estimate bulk daily sea ice growth rates over the area occupied by the seals in Commonwealth Bay during March and April using the simple 1-D salinity budget of (Charrassin et al., 2008) in Eq. (3). This method assumes the effect of horizontal advection on the freshwater budget is negligible. Clearly full-depth profiles are required to capture the total change in salinity from brine rejection. However we are limited to the dive depth of the seals and therefore this estimate will be conservative when the brine-driven overturning is deeper than our budget volume depth. In Fig. 10d-e we present the 4-day running mean time series of mean layer salinity (as in Fig. 10a) and inferred daily sea ice growth based on the $200 \mathrm{~m}$ and $300 \mathrm{~m}$ layers, which accounted for 98 and $76 \%$ of the available profiles, respectively. The time series of mean layer salinity (Fig. 10d) shows how the increase in salinity at the surface convects, creating a new homogeneous water mass from the top down. The surface and $50 \mathrm{~m}$ layer salinities are correlated through March, becoming more stratified between 16-31 March and then less so thereafter. The 50 and $200 \mathrm{~m}$ layers converge approximately two weeks later. The record shows two major peaks in the inferred daily sea ice growth rates to greater than $10 \mathrm{~cm} \mathrm{day}^{-1}$ around 8 March and 6-8 April, respectively (Fig. 10e). We identify two sustained periods of sea ice growth from the seal data, i.e., 4-29 March and 3-18 April, and estimate mean sea ice growth over these periods to be 5.1 and $7.2 \mathrm{~cm} \mathrm{day}^{-1}$, respectively.

Charrassin et al. (2008) stated the biggest error in this 1-D method of estimating sea ice production was neglecting the impact of surface freshening by precipitation. However the precipitation rates in Commonwealth Bay are likely to be small compared to the $5-10 \mathrm{~cm} \mathrm{day}^{-1}$ of sea ice growth estimated here. The largest potential source of error here is the advection of salinity, in particular from the influence of the polynyas to the east in Watt and Buchanan Bay. In the most extreme scenario, the increase in salinity in Commonwealth Bay (see Fig. 10d) could be purely the result of sea ice production in the polynya regions upstream. However the case for strong sea ice production/brine rejection in Commonwealth Bay is compelling, including the mooring data from 1998-2000 in Williams et al. (2008b) that showed a distinct input of salinity from sea ice production in the Commonwealth Bay region when comparing the Adélie Sill region to the region west of the Mertz Glacier. Assuming there is some salinity advection, then this method will overestimate sea ice growth in our study. We anticipate being able to quantify the influence of salinity advection when new mooring data from Commonwealth Bay is available, in particular instruments at depth in the Commonwealth Bay Hole.
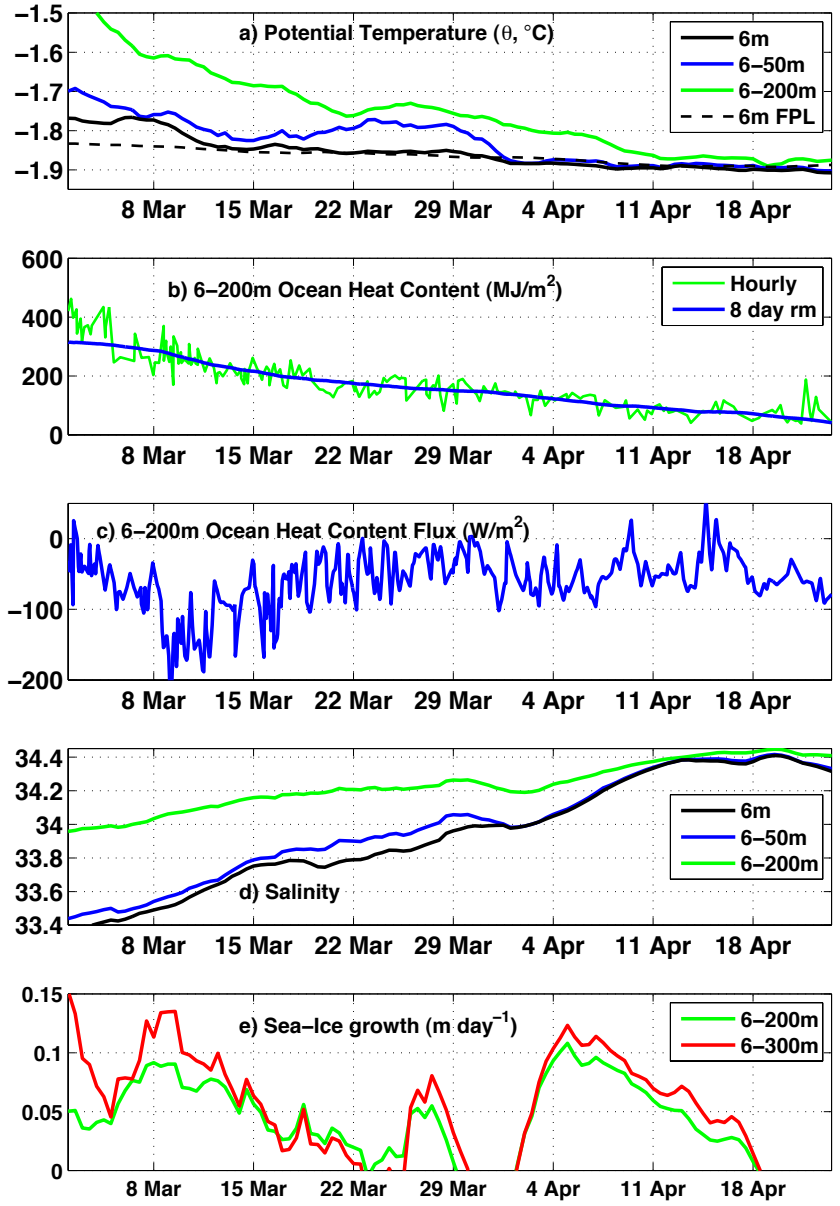

Fig. 10. Time series of ocean properties, linearly interpolated from the seal CTD data onto an hourly grid. From top to bottom, (a) Potential temperature $\left({ }^{\circ} \mathrm{C}, 4\right.$-day running mean $)$ at the near-surface (6 m, black line) and averaged over the 6-50 m (blue) and 6-200 m (green) depth range. Near-surface freezing points shown as dashed black line; b) Ocean Heat Content in the 6-200 m layer $\left(\mathrm{MJ} \mathrm{m}^{-2}\right)$ from Eq. (1). Data shown is hourly (green) and the 8-day running mean of the hourly data (blue); c) Ocean Heat Content Flux $\left(\mathrm{W} \mathrm{m}^{-2}\right.$ ) from Eq. (2), based on the 8-day running mean data (blue) shown in b); d) as in a), but for salinity and (e) Sea ice growth rates $\left(\mathrm{m} \mathrm{day}^{-1}\right)$ from the salinity budget (Eq. 3). Estimates are for the 6$200 \mathrm{~m}$ layer and 6-300 m layer (green and red, respectively). Mean sea ice growth over two sustained periods of sea ice growth from the seal data, i.e., 4-29 March and 3-18 April, are estimated to be 5.1 and $7.2 \mathrm{~cm}$ day $^{-1}$, respectively.

\subsubsection{Correlating sea ice growth to meteorological and sea ice concentration data}

From previous studies, the meteorology of Commonwealth Bay is a combination of synoptic (warm, low-pressure systems propagating from the north-west interacting with the dominant cold, high-pressure system over Antarctica) and katabatic (cold, dense gravitational winds steered into this 

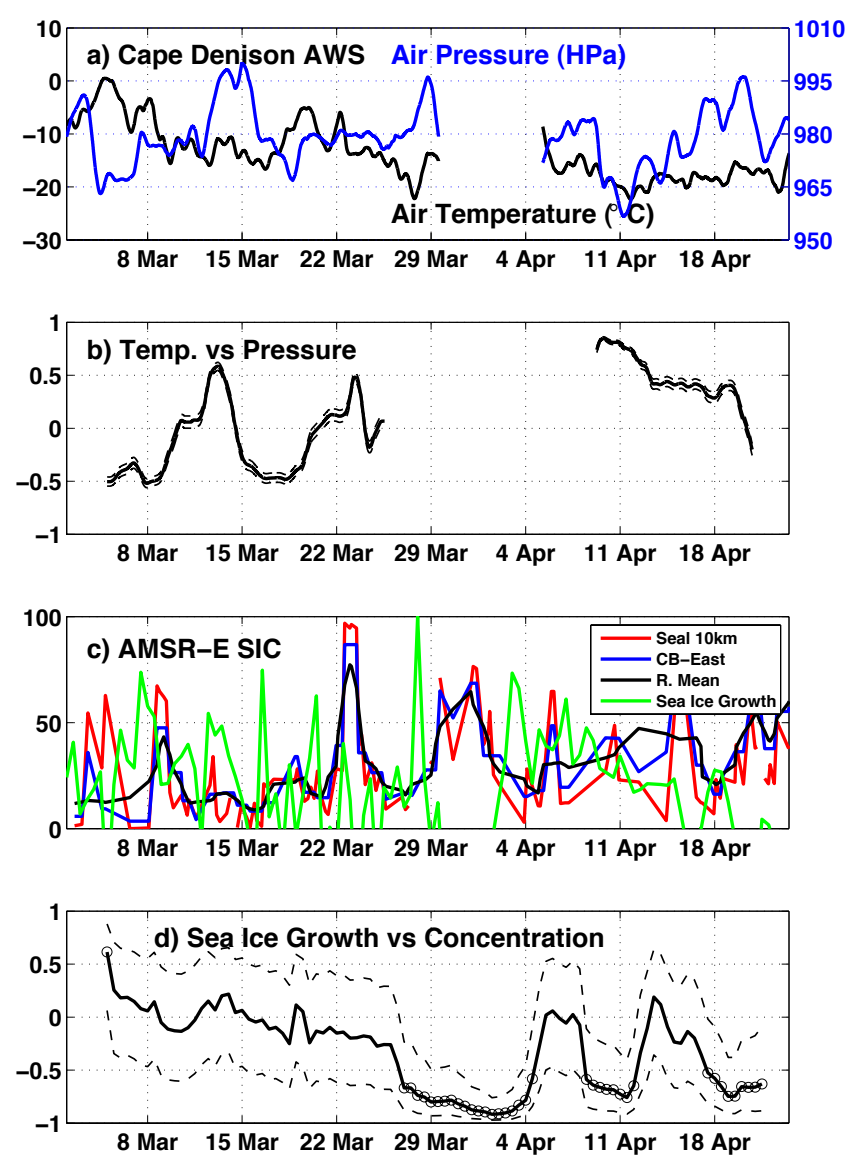

Fig. 11. Time series of: (a) AWS data from Cape Denison. Air pressure (HPa, blue, y-axis reversed) and air temperature $\left({ }^{\circ} \mathrm{C}\right.$, black); (b) Running correlation (8-day window) between linearly de-trended air pressure and temperature. Dashed lines indicate $95 \%$ confidence level; (c) Sea ice concentration (\%) with normalised sea ice growth rate estimates $(\%)$ from Fig. 10e $(6-200 \mathrm{~m})$ shown in green. Colors indicated mean value within $10 \mathrm{~km}$ radius of seal locations (red) and over the eastern sector of Commonwealth Bay (blue, with 4-day running mean in black). (d) Correlation coefficients between linearly de-trended sea ice growth (based on 6$200 \mathrm{~m}$ layer in Fig. 10e) and sea ice concentration (4-day running mean from Fig. 11c). Dashed lines indicate 95\% confidence level. Open circles indicate significant correlations $(p<0.05)$.

region by the upstream topography) processes. In terms of available data, we have at best the record of air temperature and air pressure from March through April, with missing data between the 30 March and the 5 April (Fig. 11a - note the reversal of the pressure axis). The trend upon entering and leaving this data gap suggests the influence of a decreasing pressure/increasing air temperature event over this timeframe. In the absence of wind measurements, we seek evidence of katabatic processes by examining a running correlation with an 8-day window between de-trended air temperature and pressure (Fig. 11b). The negative values in the first period, albeit punctuated by short positive events, suggest the influence of the synoptic regime (temperature and pressure are out-of-phase). In the second period (5-18 April) there is a shift to a more persistent positive correlation (temperature and pressure in-phase), implying the increasing influence of katabatic processes from April. That is, the pressure dropped significantly, but air temperatures remained cold, or decreased further, instead of increasing as expected in a synoptic regime. It is hoped that future AWS deployments can retrieve longer time-series in conjunction with robust wind data to test these ideas further.

We now consider the relationship between sea ice growth and sea ice concentration in an active polynya. The sea ice concentration is presented as the daily mean of the AMSRE estimate within a $10 \mathrm{~km}$ radius of the seal's location, and as the daily mean in the eastern sector of Commonwealth Bay (Fig. 11c). This region was identified earlier as being the centre of the low sea ice concentration in Fig. 5. The two estimates agree well, in particular during those times when the seals were sampling in the eastern sector. The sea ice growth rates over the same period (green line, Fig. 10e) are normalised and overlaid here for comparison (green line, Fig. 11c). The correlation between concentration and growth (Fig. 11d) is weak and confused in March, but there are periods of significant $(p<0.05)$ negative correlation (29 March4 April; 8-12 April and 17-20 April) in association with periods of increased sea ice concentration. One explanation for this could be a short-term negative feedback during the latter stages of a sea-ice growth period. If the polynya forms sufficient ice, without advecting it away, then the growth rate would fall in relation to the reduced ocean-atmosphere heat flux. The main caveat to our interpretation here is the potential impact of sea ice advection from outside of Commonwealth Bay. However this is likely to be negligible when the polynya is active, due to the morphology of the bay and the expected direction of the offshore wind forcing, but could be important during the inactive phase between peak events. However our time-series is too short to state this conclusively, the relationship between sea ice concentration and production being complex and requiring greater analysis of the total surface energy budget, as in Renfrew et al. (2002).

\section{Discussion}

\subsection{Validation of satellite-derived sea ice growth rates}

The assessment and monitoring of sea ice production in polynya regions is vital to our understanding of the polar climate, in particular the variability of the associated dense shelf water formation and its role in the meridional overturning circulation. Satellite-based studies of sea ice production offer the greatest coverage in time and space, but require in situ measurements from field-based studies for comparison. Sea ice production estimates were made by Williams and Bindoff (2003), for the polynya region adjacent to the MGT, 


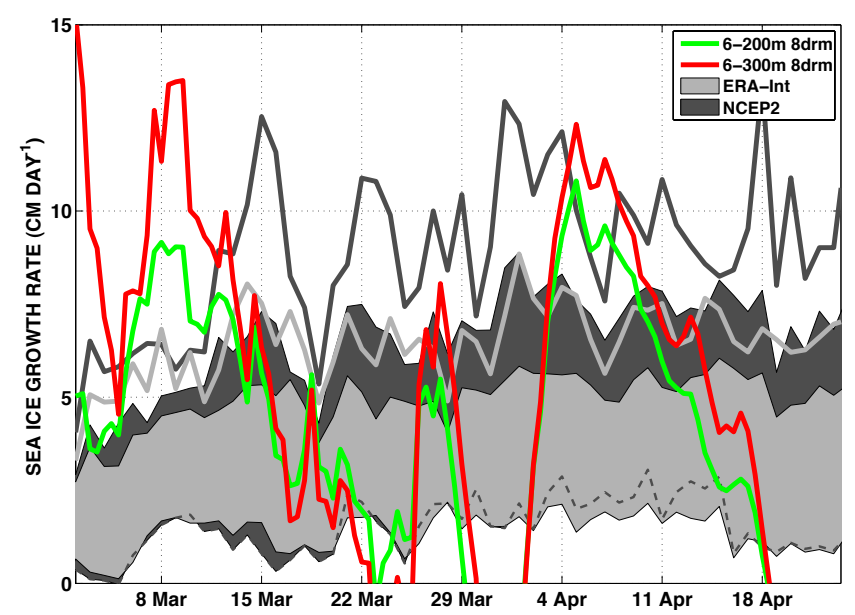

Fig. 12. Comparison of seal-derived (this paper) and satellitederived (following Tamura et al. (2008), using ERA-Interim and NCEP-2 data) sea ice growth rates. Time series of seal-derived sea ice growth rates $\left(\mathrm{m} \mathrm{day}^{-1}\right)$ are from Fig. $10 \mathrm{e}(6-200 \mathrm{~m}$ in green, $6-300 \mathrm{~m}$ in red). The shaded areas represent one standard deviation either side of the mean daily satellite-derived sea ice growth rates over the entire Commonwealth Bay polynya area from 1992-2007. Results are shown for NCEP-2 data (dark gray shaded area) and ERA-Interim data (light gray shaded area), respectively. The maximum daily satellite-derived values are shown as thick lines (again, NCEP-2 is dark gray, ERA-Interim light gray). As in the caption for Fig. 10, the mean sea ice growth estimated from both satellite datasets, over the two sustained periods of sea ice growth from the seal data, i.e., 4-29 March and 3-18 April, between 1992-2007, are 3.3 and $4.3 \mathrm{~cm} \mathrm{day}^{-1}$, respectively.

using heat and freshwater budgets around a near-closed loop of ship-based CTD measurements and an assumption that active sea ice formation occurred over a $20 \mathrm{~km}^{2}$ area. Commonwealth Bay was not sampled during this experiment due to logistic constraints, as the sea ice to the north was too thick ( $>5 \mathrm{~m}$ thick) for the RV Aurora Australis to break. Therefore the sea ice growth estimates in this paper are unique, in both the timing (during the summer/fall transition) and location.

The most current satellite-based estimates of sea ice growth come from the heat-flux algorithm for thin-ice presented by Tamura et al. $(2007,2008)$ using the NCEP-2 and ERA-40 datasets. Tamura et al. (2008) showed how these data agreed well the wintertime measurements from Williams and Bindoff (2003) over the region alongside the Mertz Glacier. Williams et al. (2010a) used these data to examine the regional variability of mean annual ice production from 1992-2005 and found that the Commonwealth Bay polynya region had maximum annual production rates of $\sim 15 \mathrm{~m}$ which produced on average $25-40 \mathrm{~km}^{3}$ of sea ice per year, or $10-15 \%$ of the sea ice production over the Adélie Depression.

Here we compare the seal-derived estimates from this study with an update to the Tamura et al. (2008) satellite- derived estimates that uses ERA-Interim data, instead of ERA-40 data, between 1992-2007 (Tamura et al., 2011). At the time of publication, the satellite-derived estimates for March-April 2010 necessary for direction comparison with the seal data were not available. Figure 12 shows one standard deviation of the mean daily sea ice growth rates from 1992-2007 from NCEP-2 (dark gray shaded area) and ERAInterim (light gray shaded area), respectively. The maximum daily growth rates for the same period are shown for each case as dark and light gray lines. For the purposes of this study we assume that these NCEP-2 and ERA-Interim estimates represent upper and lower bounds, respectively. The seal-derived results from this study include the $200 \mathrm{~m}$ and $300 \mathrm{~m}$ layer estimates from Fig. 10e, as green and red lines, respectively. For the same periods of sea-ice growth identified earlier from the seal data, i.e., the 4-29 March and 3-18 April, the mean satellite-derived sea ice growth rates for the same dates, over the 1992-2007 period, were 3.3 and $4.3 \mathrm{~cm} \mathrm{day}^{-1}$, respectively. While this is lower than the seal-derived estimates $\left(5.1\right.$ and $7.2 \mathrm{~cm} \mathrm{day}^{-1}$, respectively), the magnitude of the maximum mean daily growth rates for March and April from 1992-2007 are between 7$12 \mathrm{~cm} \mathrm{day}^{-1}$ and are in good agreement with the seal results. As mentioned earlier, our 1-D calculation could overestimate sea ice growth, as it currently neglects the influence of salinity advection from the coastal polynyas to the east of Commonwealth Bay.

Nonetheless, this result is very promising for the longterm monitoring of sea ice growth using satellites. When the data becomes available for the 2010 season there will be further opportunity to examine the temporal variability of the sea ice growth on shorter time-scales, in particular the 2-3 "peak events" discerned from the in situ estimates. Care will be needed in assessing the sources of error for both satellite-derived and in situ estimates. As discussed earlier, our estimates are likely to be conservative because they are not based on the full-depth salinity budget. Additionally our method provides a bulk estimate over a wide area and is therefore likely to smooth over peak sea ice growth rates in the peak polynya regions against the coast. For example, helicopter-borne observations in August 1999, over the polynya region in Buchanan Bay, where the Mertz Glacier departs the coast, estimated sea ice growth rates as high as $20 \mathrm{~cm} \mathrm{day}^{-1}$ (Roberts et al., 2001).

\subsection{New insights into the oceanography of the Adélie Depression}

As detailed in the Introduction, ship-based CTD data from Antarctic fieldwork is typically limited to the ice-free season in the austral summer and surveys outside of this are rare and relatively limited in spatial coverage. The only wintertime survey of the Adélie Depression in July-September 1999 experienced very thick sea ice over the south-western sector of the Adélie Depression and was unable to reach 


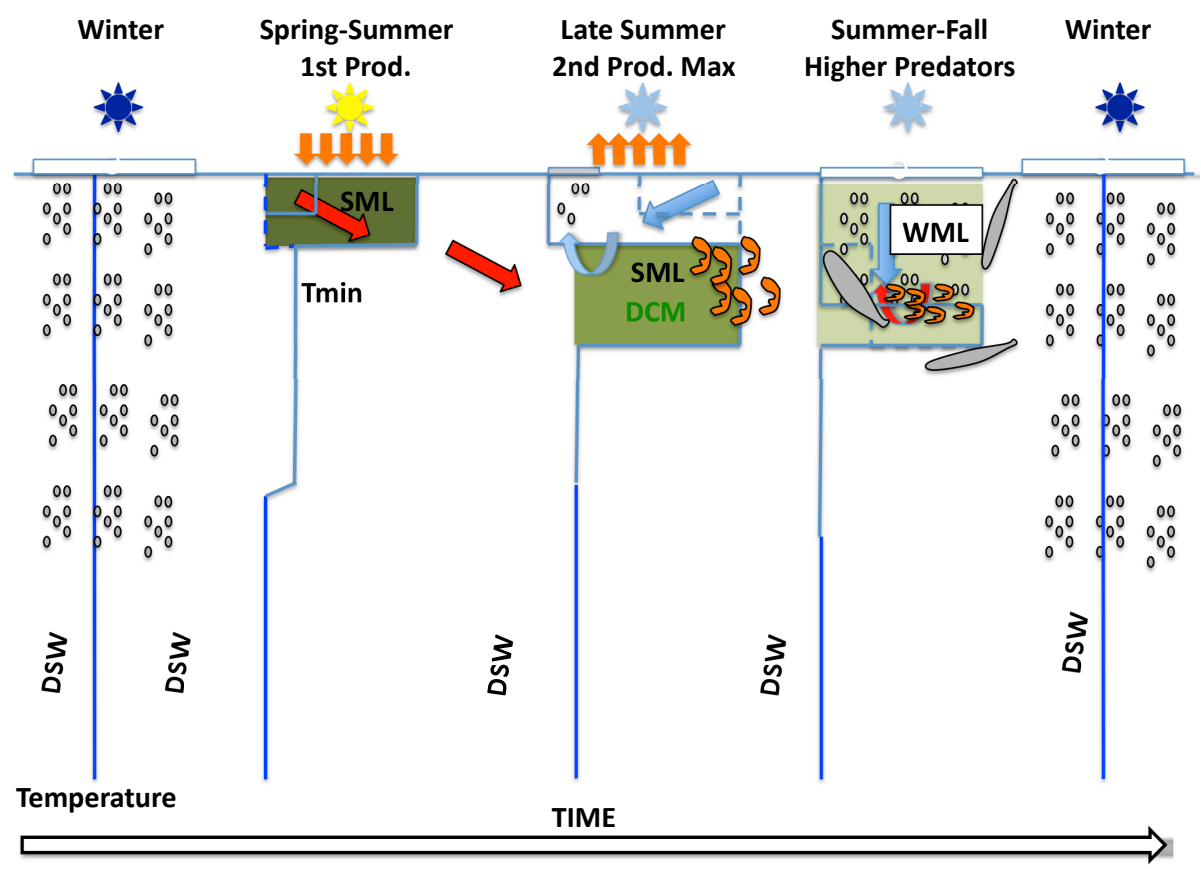

Fig. 13. Schematic of seasonal evolution that leads to the foraging behavior of the IMOS seals in Commonwealth Bay during the summer-fall transition (March through April). In winter the entire water column is near homogeneous at the freezing point and gains salinity from sea ice growth/brine rejection. In summer a SML develops above the remnant winter mixed layer (or $T_{\min }$ layer). In Commonwealth Bay a particularly deep SML develops in conjunction with a deep chlorophyll maximum. At the end of summer, atmospheric cooling brings the surface waters back to the freezing point, initiating sea ice growth and the development of the new winter mixed layer. During the summerfall transition the remnant SML is eroded by convection of the upper layer. Our hypothesis is that the seals forage here at this time to take advantage of the secondary production (fish, krill etc) that have responded to the primary production of the DCM earlier in summer.

the Commonwealth Bay at all. While there have been advances in the ARGOS system, with new Ice-ARGO floats capable of making CTD measurements beneath sea ice outside of this summer period, these are limited to depths greater than 2000-3000 $\mathrm{m}$ and therefore do not observe the coastal/continental shelf region. Similarly there are mooring arrays that offer year-round observations beneath, such as the Mertz Polynya Experiment, but do not adequately observe the upper surface water column due to the threat from icebergs.

In 2010 the two IMOS seals that travelled to the AGV coast, collected the first observations of upper water mass transformations beneath newly-formed sea ice in a polynya during the summer/fall transition. Williams et al. (2008a) referred to this late summer/early autumn period as the 'conditioning' phase where the remnant summertime water masses are convected, first by atmospheric cooling and preliminary sea ice formation in preparation for the development of the winter mixed layer during the sea ice growth period in winter. However in that study there was no direct measurement of this process since the shallowest instrument in this was around $375 \mathrm{~m}$. The IMOS seals have successfully overcome this data gap, acting as the first moored CTD profiler over the surface layer (consistently down to $300 \mathrm{~m}$ ) in a polynya region against the Antarctic coast. The resulting data has clearly shown the erosion of the summer mixed layer after the surface reaches the freezing point and the new sea ice season begins.

Ocean heat content has been estimated before from sealmounted temperature sensors by Costa et al. (2008), specifically in the region of the West Antarctic Peninsula during the fall-winter period (April-August). Costa et al. (2008) showed there was strong variability over this region associated with the greater influence of Circumpolar Deep Water. Our study has shown that ocean heat content in Commonwealth Bay trends to zero after the remnant summer mixed layer has been eroded. This means the Commonwealth Bay polynya is solely a latent-heat polynya. The implication that $\mathrm{mCDW}$ does not penetrate into this region agrees with the spatial distribution of mCDW from summertime surveys (Fig. 4a). This is different to the polynya area over the greater Adélie Depression against the pre-calving position of the MGT, where Williams and Bindoff (2003) determined that mCDW, albeit highly modified through cross-shelf exchange with the newly formed winter mixed layer on the shelf, provided a small but detectable ocean heat flux to the region.

This study has demonstrated the processes of the summer/fall transition that (a) recondition the surface water column in the polynya back to the near-surface freezing point necessary to initiate sea ice growth and then (b) remove the 
salt deficit and sub-surface heat content to initiate full convective overturning of the winter mixed layer and new shelf water formation. The timing of these processes is relative to the air-sea interactions driving them and the initial stratification of the upper water column at the end of summer, influenced by the SML properties and presence/absence of mCDW. Regions with shallow/weak SMLs and/or minimal penetration from mCDW can therefore be expected to start the sea ice growth season, and subsequent shelf water formation earlier. It follows that any regional changes to these processes in future climate scenarios will lead to the changes in the start of the sea ice growth/shelf water season. More work is required to completely understand the temporal and spatial variability of mCDW around Antarctica relative to the major polynya regions.

\subsection{Utilisation of oceanographic processes in elephant seal foraging behavior}

This study has revealed not only physical oceanographic processes, but also shed some light onto how the elephant seals are utilising these processes in their behavior. We would like to now suggest four physical processes that possibly influenced the foraging strategies, namely: (i) the calving of the MGT; (ii) the Antarctic Slope Current; (iii) the cross-shelf pathways of modified Circumpolar Deep Water; (iv) and the late summer overturning of the upper surface layer in Commonwealth Bay. Beginning with the seals response to the calving event, we showed in Fig. $1 \mathrm{~b}$ that seals I1 and I2 both changed direction from SSE to SSW between the 1114 February, which corresponds to the calving event of the MGT. The ocean is an excellent medium for the transmission of sound and there has been detection of calving events around Antarctica by acoustic instruments in West Australia (Gavrilov and Vazques, 2005) and beyond (Talandier et al., 2002). We note that only two out of fifteen of the IMOS seals decided to go to the AGV region, and that seals have visited the AGV region before, in years when there wasn't a calving event, i.e. seals S1 and S2 from the SEaOS deployments. Nonetheless this was the first time that seals penetrated beyond the shelf break itself and both seals "investigated" the iceberg C-28 once there.

The second oceanographic process that appears to be utilised by the seals, in particular in the $\mathrm{SEaOS}$ deployment, is the westward Antarctic Slope Current (ASC) over the upper continental slope. This region is documented around other regions of East Antarctica as having a narrow, fastflowing westward jet $\left(20-30 \mathrm{~cm}^{-1}\right)$ that is vertically homogeneous and pinned to the $1000 \mathrm{~m}$ isobath (Williams et al., 2008b; Meijers et al., 2010; Williams et al., 2010b). While elephant seals can and do move independently of ocean currents and are not expected to act like Lagrangian floats, they are known to periodically operate in "drift mode", during which time they could be expected to "go with the flow". Figure 2 showed that seal S2, after initially investigating the polynya region in the vicinity of the Mertz Bank and Mertz Depression, travelled westwards from $147-141^{\circ} \mathrm{E}$. We estimate a mean "drift" speed of $17.5 \mathrm{~cm} \mathrm{~s}^{-1}$ along this path, which is conservative given the extra time taken to complete a minimum of twelve dives plus additional random movements. This does not provide a robust observation of the ASC, however as it is in reasonable agreement with the reported speeds of the ASC jet in other regions, it does suggest the ASC exists across the AGV slope and that the seal was utilising it in its movement.

In both SEaOS and IMOS deployments, the seals that travelled to the AGV region all approached the continental shelf break between $146-148^{\circ} \mathrm{E}$. As discussed in an earlier section, this is a region of mCDW penetration across the shelf break. Based on these two surveys we speculate that this is the third oceanographic process the seals are using, i.e. the upwelling of warm, saline mCDW onto and across the continental shelf break, as a preferential pathway into the continental shelf region. Potential benefits include the energy saved by staying in warmer water and going with the flow. Again it is difficult to speculate on the robustness of this assertion with only two years of data. Future work examining the dive behavior of the seals will explore in greater detail their interaction with the processes of the Antarctic Slope Front.

The repeat foraging in Commonwealth Bay in conjunction with the summer/fall re-conditioning of the upper water column is a final example of bio-physical coupling utilised by the IMOS seals. Given the short amount of time the SEaOS seals spent foraging in the early stage of the polynya near the Mertz Bank, we consider that something different was keeping the IMOS seals, in particular I2, diving and feeding in Commonwealth Bay for close to two months. One of the key summertime observations from the NBP00-08 survey in January 2001 was the deep chlorophyll maximum associated with well-developed seasonal (summer) mixed layer in the Commonwealth Bay region. This was attributed to the subduction from a shoreward driven Ekman transport that resulted from the strong south-easterly katabatic wind regime in this region (Vaillancourt et al., 2003; Sambrotto et al., 2003). One explanation for why the IMOS seals foraged so heavily in this region relates to this phenomenon. In our simple hypothesis (see Fig. 13) we suggest that in early summer the conditions in Commonwealth Bay promote elevated primary production that is ultimately pushed below the euphotic zone, possibly allowing even greater production to continue above. In the latter half of summer we suggest there could be increased secondary production in response to the primary production. Finally we conclude that when the water column begins to overturn during the summer/fall transition there is enhanced food availability for any seals, and possibly their prey, willing to stay within the growing pack of the new sea ice season. 


\section{Conclusions}

Southern elephant seals (Mirounga leonina), fitted with Conductivity-Temperature-Depth sensors at Macquarie Island in January 2005 and 2010, collected unique oceanographic observations of the Adélie and George V Land continental shelf $\left(140-148^{\circ} \mathrm{E}\right)$ from late February through April. In this paper we presented these data and the new insights gained into the oceanography of this region during the summer-fall transition. The seal data added a new latesummer snapshot from 2005 of the zonal distribution of modified CDW exchange across the shelf break, that extended further east than previous observations, and showed a strong mCDW signal $\left(\theta\right.$ up to $\left.0^{\circ} \mathrm{C}\right)$ near $140^{\circ} \mathrm{E}$ in addition to the known regions of mCDW inflow east of the Adélie Sill. Seal transects across the Adélie Depression, including alongside iceberg C-28 that calved from the Mertz Glacier, demonstrated the late summer stratification, with the SML above modified CDW at mid-depths. These highlighted the reconditioning required to return the water column to the winter state necessary to form dense shelf water, i.e., full-depth homogeneity at the freezing point with increasing salinity from brine rejection. This was confirmed by the near-repeat CTD profiling conducted by the IMOS seals from March through April in Commonwealth Bay, one of the key polynya regions, which captured the convective overturning of the deep remnant SML at the beginning of the sea ice growth season. Heat and freshwater budgets to $200-300 \mathrm{~m}$ were used to estimate the ocean heat content $\left(400 \rightarrow 50 \mathrm{MJ} \mathrm{m}^{-2}\right)$, flux (50$200 \mathrm{~W} \mathrm{~m}^{-2}$ loss) and sea ice growth rates (maximum of 7.5$12.5 \mathrm{~cm} \mathrm{day}^{-1}$ ). Mean seal-derived sea ice growth rates were within the range of satellite-derived estimates from 19922007 using ERA-Interim data. The heat content time series showed that the contribution of heat from advection was minimal and confirmed that Commonwealth Bay is primarily a latent-heat polynya region. We have demonstrated that these seal-derived data are invaluable in filling in previous gaps in our understanding of the temporal and spatial variability of the Antarctic coastal region. In particular the results in this paper will provide useful benchmarks for examining the satellite and model derived estimates of sea ice growth necessary for future monitoring and prediction of this important source region of Antarctic Bottom Water.

Acknowledgements. This work was supported by the Marie de Paris "Research in Paris" program. SEaOS and IMOS Seal-CTD data was provided through the Australian Animal Tracking and Monitoring System, a facility of Integrated Marine Observing System. The Australian Antarctic Division provided in-kind support. Field work was done in compliance with research permits supplied by the Tasmania Government's Department of Primary Industry, Water and the Environment. Animal ethics for all animal handling was approved by the University of Tasmania and Macquarie University's Animal Ethics Committees. Support for the NBP00-08 and NBP04-10 research voyages (contact S. S. Jacobs, Lamont-Doherty Earth Observatory, USA) was provided by the
US National Science Foundation with the data processed and archived with the National Oceanographic Data Center. Support for the AU9901 (contact N. L. Bindoff, ACECRC, Australia) research voyage provided by the Australian Antarctica Division. The authors was like to thank the officers, crew and technicians of the RVIB Nathaniel B Palmer and R/V Aurora Australis for their professional support in the collection of these observational data.

Edited by: R. Muench

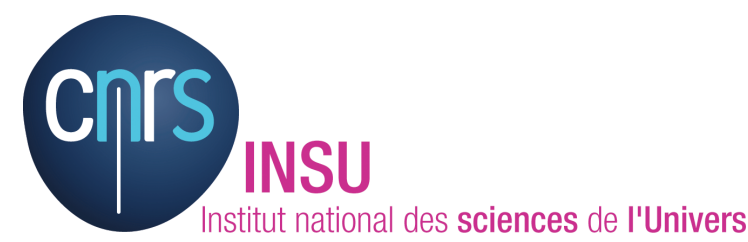

The publication of this article is financed by CNRS-INSU.

\section{References}

Adolphs, S. and Wendler, G.: A pilot study on the interactions between katabatic winds and polynyas at the Adélie Coast, Eastern Antarctica, Antarct. Sci., 7, 307-314, 1995.

AMSR-E: Daily Updated AMSR-E Sea Ice Maps, http://www.iup. uni-bremen.de:8084/amsr/amsre.html, 2008.

Aoki, S.: Seasonal and Spatial Variations of Iceberg Drift off Dronning Maud Land, Antarctica, Detected by Satellite Scatterometers, J. Oceanogr., 59, 629-635, 2003.

AWS: Cape Denison, http://amrc.ssec.wisc.edu/aws/ capedenisonmain.html, 2010.

Bailleul, F., Charrassin, J., Monestiez, P., Roquet, F., Biuw, M., and Ginot, C.: Successful foraging zones of southern elephant seals from the Kerguelen Islands in relation to oceanographic conditions, Philosophical transactions Royal Society Biological Sciences, 1487, 2169-2181, 2007.

Beaman, R.: A bathymetric Digital Elevation Model (DEM) of the George $\mathrm{V}$ and Terre Adélie continental shelf and margin, World Wide Web electronic publication, http://data.aad.gov.au/aadc/metadata/metadata_redirect.cfm? md\%=AMD/AU/GVdem_2008, 2009.

Biuw, M., Boehme, L., Guinet, C., Hindell, M., Costa, D., Charrassin, J.-B., Roquet, F., Bailleul, F., Meredith, M., Thorpe, S., Tremblay, Y., McDonald, B., Park, Y.-H., Rintoul, S. R., Bindoff, N., Goebel, M., Crocker, D., Lovell, P., Nicholson, J., Monks, F., and Fedak, M. A.: Variations in behavior and condition of a Southern Ocean top predator in relation to in situ oceanographic conditions, Proceedings of the National Academy of Sciences of the United States of America, 104, 34, 13705-13710, 2007.

Boehme, L., Meredith, M. P., Thorpe, E., Biuw, M., and Fedak, M.: Antarctic Circumpolar Current frontal system in the South Atlantic: Monitoring using merged Argo and animal-borne sensor data, J. Geophys. Res., 113, doi:10.1029/2007JC004647, 2008.

Charrassin, J.-B., Hindell, M., Rintoul, S. R., Roquet, F., Sokolov, S., Biuw, M., Costa, D., Boehme, L., Lovell, P., Coleman, R., Timmermann, R., Meijers, A., Meredith, M., Park, Y.-H., Bailleul, F., Goebel, M., Tremblay, Y., Bostk, C.-A., McMahon, C. R., Field, I. C., Fedak, M. A., and Guinet, C.: Southern Ocean 
frontal structure and sea-ice formation rates revealed by elephant seals, Proceedings of the National Academy of Sciences of the United States of America, 105, 11634-11639, 2008.

Costa, D. P., Klinck, J. M., Hoffman, E. E., Dinniman, M. S., and Burns, J. M.: Upper ocean variability in west Antarctic Peninsula continental shelf waters as measured using instrumented seals, Deep-Sea Res. Pt. II, 55, 323-337, 2008.

ETOPO1: Global Predicted Bathymetry V11. Smith, W. H. F. and D. Sandwell, Global seafloor topography from satellite altimetry and ship depth soundings, Science, 277, 1956-1962, 1997., http: //topex.ucsd.edu/marine/topo/, 2009.

Gavrilov, A. and Vazques, G.: Detection and localization of ice rifting and calving events in Antarctica using remote hydroacoustic stations, in: Proceedings of ACOUSTICS 2005, 2005.

Gordon, A. L. and Tchernia, P.: Waters of the continental margin off Adélie coast, Antarctica, Antarctic Research Series, Antarctic Oceanolgy II: The Australian-New Zealand Sector, edited by: Hayes, D. E., Washington, American Geophysical Union., edited by: Gascard, J. and Chu, P., New York, Elsevier, 59-69, 1972.

Jacobs, S. S., Merle, P. A., Smethie, W. M., and Mortlock, R. A.: Summer Oceanographic Measurements near the Mertz Polynya $\left(140-150^{\circ} \mathrm{E}\right)$ on NB Palmer Cruise 00-08, Tech. Rep. LDEO2003-3, LDEO, 2004.

Kusahara, K., Hasumi, H., and Williams, G.: Impact of Mertz Glacier Tongue Calving on Dense Shelf Water, Nature Communications, 2:159, doi:10.1038/ncomms1156, 1-6, 2011a.

Kusahara, K., Hasumi, H., and Williams, G.: Dense Shelf Water Formation and Brine-Driven Circulation in the Adélie Depression, Ocean Modelling, 2011b.

Marsland, S. J., Bindoff, N. L., Williams, G. D., and Budd, W. F.: Modeling water mass formation in the Mertz Glacier Polynya and Adélie Depression, East Antarctica, J. Geophys. Res., 109, C11003, doi:10.1029/2004JC002441, 2004.

Marsland, S. J., Church, J., Bindoff, N. L., and Williams, G. D.: Antarctic coastal polynya response to climate change, J. Geophys. Res., 112, C07009, doi:10.1029/2005JC003291, 2007.

Massom, R., Hill, K., Lytle, V. I., Worby, A. P., Paget, M. J., and Alison, I.: Effects of regional fast-ice and iceberg distributions on the behavior of the Mertz Glacier Polynya, East Antarctica, Ann. Glaciol., 33, 391-398, 2001.

Mawson, D.: The Home of the Blizzard, Hodder and Stoughton, London," "Abridged popular edition" of original published in 1915 by William Heineman, London; reprinted in facsimile in 1996 by Wakefield Press, South Australia, 438 pp, 1930.

Meijers, A., Klocker, A., Bindoff, N. L., Williams, G. D., and Marsland, S. J.: The large-scale circulation off the East Antarctic coast $\left(30-80^{\circ} \mathrm{E}\right)$, Deep-Sea Res. Pt. II, "BROKEWest" a Biological/Oceanographic Survey Off the Coast of East Antarctica (30-80 E) Carried Out in January-March 2006, 57, doi:10.1016/j.dsr2.2009.04.019, 2010.

Meredith, M., amd L. Boehme, I. A. R., Biuw, M., and Fedak, M. A.: Seasonal evolution of the upper-ocean adjacent to the South Orkney Islands, Southern Ocean: results from a "lazy biological mooring", Deep-Sea Res. Pt. II, in press, doi:10.1016/j.dsr2.2009.07.008, 2011.

Orsi, A. H. and Wierderwahl, C. L.: A recount of Ross Sea waters, Deep-Sea Res. Pt. II, 56, 778-795, doi:10.1016/j.dsr2.2008.10.033, 2009.

Parish, T. R. and Wendler, G.: The katabatic wind regime at Adélie
Land, Int. J. Clim., 11, 97-107, 1991.

Patterson, T., McConnell, B., Fedak, M., Bravington, M., and Hindell, M.: Using GPS data to evaluate the accuracy of state-space methods for correction of Argos satellite telemetry error, Ecology, 91(1), 273-285, 2010.

Renfrew, I., King, J., and Markus, T.: Coastal polynyas in the southern Weddell Sea: Variability of the surface energy budget, J. Geophys. Res., 107, doi:10.1029/2000JC000720, 2002.

Rintoul, S. R.: On the origin and influence of Adélie Land Bottom Water Ocean, Ice, and Atmosphere: Interactions at the Antarctic Continental Margin, Antarctic Research Series 75, edited by: Jacobs, S. and Weiss, R., Washington, American Geophysical Union, 75, 151-171, 1998.

Roberts, A., Allison, I., and Lytle, V. I.: Sensible and latent heat flux estimates over the Mertz Glacier polynya, East Antarctica, from in-flight measurements, Ann. Glaciol., 33, 377-384, 2001.

Rosenberg, M. A., Bindoff, N. L., Bray, S., Curran, C., Helmond, I., Miller, J., Lachlan, D., and Richman, J.: Mertz Polynya Experiment, Marine Science Cruises AU9807, AU9801, AU9905, AU9901 and TA0051 - Oceanographic Field Measurements and Analysis, Antarctic CRC Research Report. Hobart, Australia, 25, 1-90, 2001.

Sambrotto, R. N., Matsuda, A., Vaillancourt, R. D., Langdon, C., Brown, M., Measures, C., Jacobs, S. S., and Wells, H.: Summer plankton production and nutrient consumption patterns in the Mertz Glacier Region of East Antarctica, Deep-Sea Res. Pt. II, Recent investigations of the Mertz Polynya and George Vth Land continental margin, East Antarctica, 1393-1414, 2003.

Talandier, J., Hyvernaud, O., Okal, E., and Piserchia, P.: Longrange detection of hydroacoustic signals from large icebergs in the Ross Sea, Antarctica, Earth Planet. Sci. Lett., 203, 519-534, 2002.

Tamura, T., Ohshima, K. I., Markus, T., Cavalieri, D., Nihashi, S., and Hirasawa, N.: Estimation of thin ice thickness and detection of fast ice from SSM/I data in the Antarctic Ocean, J. Atmos. Ocean. Technol., 24, 1757-1772, 2007.

Tamura, T., Ohshima, K. I., and Nihashi, S.: Mapping of sea ice production for Antarctic coastal polynyas, Geophys. Res. Lett., 35, doi:10.1029/2007GL032903, 2008.

Tamura, T., Ohshima, K. I., Nihashi, S., and Hasumi, H.: Estimation of surface heat/salt fuxes associated with sea ice growth/melt in the Southern Ocean, Scientific Online Letter on the Atmosphere, 7, doi:10.2151/sola.2011-005, 17-20, 2011.

Vaillancourt, R. D., Sambrotto, R. N., Green, S., and Matsuda, A.: Phytoplankton biomass and photosynthetic competency in the summertime Mertz Glacier Region of East Antarctica, DeepSea Res. Pt. II, Recent investigations of the Mertz Polynya and George Vth Land continental margin, East Antarctica, 14151440, 2003.

Vincent, C., McConnell, B., Bidoux, V., and Fedak, M.: Assessment of Argos location accuracy from satellite tags deployed on captive gray seals, Marine Mammal Science, 18, 156-166, 2002.

Whitworth III, T.: Two modes of bottom water in the Australian-Antarctic Basin, Geophys. Res. Lett., 29(5), doi:10.1029/2001GL014282, 2002.

Williams, G. D.: Adélie Land Bottom Water Production, Ph.D. thesis, University of Tasmania, 2004.

Williams, G. D. and Bindoff, N. L.: Wintertime oceanography of the Adélie Depression, Deep-Sea Res. Pt. II, Recent investiga- 
tions of the Mertz Polynya and George Vth Land continental margin, East Antarctica, 1373-1392, 2003.

Williams, G. D., Bindoff, N. L., Marsland, S. J., and Rintoul, S. R.: Formation and export of dense shelf water from the Adélie Depression, East Antarctica, J. Geophys. Res., 113, C04039, doi:10.1029/2007JC004346, 2008a.

Williams, G. D., Nicol, S., Raymond, B., and Meiners, K.: On the summertime mixed layer development in the marginal seaice zone off the Mawson coast, East Antarctica, Deep Sea Res. Pt. II, Dynamics of Plankton, Krill, and Predators in Relation to Environmental Features of the Western Antarctic Peninsula and Related Areas: SO GLOBEC Part II., 55(3-4), doi:10.1016/j.dsr2.2007.11.007, 365-376, 2008b.
Williams, G. D., Aoki, S., Jacobs, S. S., Rintoul, S. R., Tamura, T., and Bindoff, N. L.: Antarctic Bottom Water from the Adélie and George V Land coast, East Antarctica (140-149 ${ }^{\circ}$ E), J. Geophys. Res., 115, C04027, doi:10.1029/2009JC005812, 2010a.

Williams, G. D., Nicol, S., Aoki, S., Meijers, A. J. S., Bindoff, N. L., Iijima, Y., Marsland, S. J., and Klocker, A.: Surface oceanography of BROKE-West, along the Antarctic margin of the south-west Indian Ocean $\left(30-80^{\circ} \mathrm{E}\right)$, Deep-Sea Res. Pt. II, "BROKE-West" a Biological/Oceanographic Survey Off the Coast of East Antarctica $\left(30-80^{\circ} \mathrm{E}\right)$ Carried Out in JanuaryMarch 2006, 57, doi:10.1016/j.dsr2.2009.04.020, 2010b. 